DOI: $10.19195 / 0524-4544.325 .10$

\author{
ŁUKASZ BASZAK \\ ORCID: 0000-0002-7895-7983 \\ Uniwersytet Wrocławski \\ lukasz.baszak@uwr.edu.pl
}

\title{
Obowiązki stron w umowie o pracę w Kodeksie zobowiązań z 1933 roku
}

\section{Wstęp}

Ustawodawstwo związane z prawem pracy w okresie II Rzeczypospolitej było dość obszerne, a poszczególne zagadnienia zostały uregulowane w wielu aktach prawnych ${ }^{1}$. Umowę o pracę regulowały przepisy art. 441-477 Kodeksu zobowiązań (dalej: k.z.) ${ }^{2}$ z 1933 roku oraz przepisy szczególne odnoszące się do poszczególnych kategorii pracowników, czyli dla pracowników umysłowych było to rozporządzenie Prezydenta Rzeczypospolitej z dnia 16 marca 1928 roku

1 Poszczególne zagadnienia prawa pracy regulowane były odrębnymi ustawami lub rozporządzeniami, np. dotyczącymi czasu pracy (ustawa z dnia 18 grudnia 1919 roku o czasie pracy w przemyśle i handlu, Dz.U. z 1920 r. Nr 2, poz. 7); ochrony pracy młodocianych i kobiet (ustawa z dnia 2 sierpnia 1924 roku w przedmiocie pracy młodocianych i kobiet, Dz.U. z 1924 r. Nr 65, poz. 636), zob. szerzej J. Jończyk, Ochrona pracy kobiet i młodocianych w polskim przemyśle w latach 1918 1939, Warszawa 1961; urlopów (ustawa z dnia 16 maja 1922 roku o urlopach dla pracowników zatrudnionych w przemyśle i handlu, Dz.U. z 1922 r. Nr 40, poz. 334); spraw związanych z bezpieczeństwem i higieną pracy (rozporządzenie z dnia 16 marca 1928 roku o bezpieczeństwie i higienie pracy, Dz.U. z 1928 r. Nr 35, poz. 325); inspekcją pracy (rozporządzenie z dnia 14 lipca 1927 roku o inspekcji pracy Dz.U. z 1927 r. Nr 67, poz. 590); ochroną rynku (rozporządzenie z dnia 4 czerwca 1927 roku o ochronie rynku pracy, Dz.U. z 1927 r. Nr 54, poz. 472); lub sądów pracy (rozporządzenie z dnia 24 października 1934 roku Prawo o sądach pracy, Dz.U. z 1934 r. Nr 95, poz. 854). Z obowiązujących na ziemiach polskich pozaborowych kodeksów cywilnych kodeks Napoleona nie zawierał prawie żadnych przepisów o umowie o pracę, natomiast w kodeksie cywilnym austriackim (ABGB) oraz niemieckim (BGB) umowie o pracę poświęcono specjalne rozdziały, zob. Z. Fenichel, Charakterystyka przepisów o umowie o prace w kodeksie zobowiązań, [w:] idem, Polskie prawo prywatne i procesowe. Studia, Kraków 1936, s. 330-334.

2 Dz.U. z 1933 r. Nr 82, poz. 598. 
o umowie o pracę pracowników umysłowych ${ }^{3}$ (dalej: rozp. o um. o pr. prac. um.), a dla robotników - rozporządzenie Prezydenta Rzeczypospolitej Polskiej z dnia 16 marca 1928 roku o umowie o pracę robotników ${ }^{4}$ (dalej: rozp. o um. o pr. rob.). Warunki pracy robotników portowych uregulowano osobno ${ }^{5}$ poprzez wydanie rozporządzenia Prezydenta Rzeczypospolitej z dnia 27 października 1933 roku o pracy robotników portowych w Gdyni ${ }^{6}$. Poza tym źródłem norm regulujących umowy o pracę były układy zbiorowe, które zawierano pomiędzy pracodawcami lub związkami pracodawców a związkami pracowników. Ogólne postanowienia o układach zbiorowych pracy zawarto $\mathrm{w}$ art. 445 k.z. ${ }^{7}$ oraz $\mathrm{w}$ ustawie ${ }^{8} \mathrm{z}$ dnia 14 kwietnia 1937 roku o układach zbiorowych pracy.

W k.z. szczegółowo unormowano umowę o pracę. Zgodnie z art. 42 ust. 1 przepisów wprowadzających kodeks zobowiązań ${ }^{9}$ przepisy k.z. weszły w życie w całej rozciągłości do istniejących zobowiązań z umów o pracę po upływie roku od wejścia w życie k.z., to jest od 1 lipca 1935 roku. Jednak w samym tekście k.z. wystąpiło odstępstwo od tej zasady. Wedle art. 446 k.z., jeżeli dla pewnej kategorii pracowników istniała lub wydana będzie szczególna ustawa regulująca stosunek pracy, przepisy działu o umowie o pracę będą miały zastosowanie jedynie w przedmiotach nieobjętych ustawą szczególną. W związku z przepisem art. 446 k.z. art. 2

3 Dz.U. z 1928 r. Nr 35, poz. 323; szerzej o regulacjach zawartych w tym rozporządzeniu zob. Ł. Baszak, Regulacje prawne umowy o pracę robotników w latach 1928-1939, „Folia Iuridica Universitatis Wratislaviensis" 2017, nr 2, s. 9-30; oraz w podanej tam literaturze.

4 Dz.U. z 1928 r. Nr 35, poz. 324; szerzej o regulacjach zawartych w tym rozporządzeniu zob. Ł. Baszak, Regulacje prawne umowy o pracę pracowników umysłowych w latach 1928-1939, „Folia Iuridica Universitatis Wratislaviensis” 2016, nr 5, s. 9-23; oraz w podanej tam literaturze.

5 Warunki pracy robotników portowych w Gdyni określały odrębne przepisy rozporządzenia Prezydenta Rzeczypospolitej z dnia 27 października 1933 roku (Dz.U. z 1933 r. Nr 85, poz. 646). W rozumieniu tego rozporządzenia robotnikiem portowym był robotnik zatrudniany przy przeładunku portowym, uznany za robotnika portowego przez Komisję Kwalifikacyjną i zarejestrowany w Biurze Pośrednictwa dla robotników portowych w Gdyni. Szczegóły regulowane były m.in. rozporządzeniem Ministra Opieki z dnia 27 marca 1935 roku o Biurze Pośrednictwa pracy dla robotników portowych w Gdyni (Dz.U. z 1935 r. Nr 23, poz. 153), rozporządzeniem Ministra Opieki Społeczej z dnia 29 marca 1934 roku w sprawie książeczek obrachunkowych dla robotników portowych (Dz.U. z 1934 r. Nr 32, poz. 289); zob. I. Rosenblüth, Pracy prawo, [w:] Encyklopedia podręczna prawa prywatnego, t. 3, Warszawa 1937, s. 1690.

6 Dz.U. z 1933 r. Nr 85, poz. 646.

7 Art. 445 k.z.: „§ 1. Układ co do warunków umów indywidualnych o pracę, zawarty między pracodawcą albo prawnie istniejącym związkiem pracodawców z jednej strony a prawnie istniejącym związkiem pracodawców z drugiej strony (układ zbiorowy), wiąże, w braku szczególnego przepisu ustawy, tylko strony, które układ zawarły, oraz członków związku, będącego stroną. $§ 2$. Układ zbiorowy powinien być pod nieważnością zawarty na piśmie".

${ }^{8}$ Dz.U. z 1937 r. Nr 31, poz. 242; szerzej o układach zbiorowych zob. I. Rosenblüth, Układy zbiorowe pracy: komentarz. Ustawa o uktadach zbiorowych pracy. Rozporzadzenia wykonawcze. Wyciagi z motywów ustawodawczych. Przepisy zwiazkowe. Zatargi zbiorowe. Wzory uktadów zbiorowych pracy i innych aktów prawnych, Kraków 1937. Zob. też R. Longchamps de Bérier, Polskie prawo cywilne, t. 2. Zobowiąania, Lwów 1938, s. 518-521.

9 Dz.U. z 1933 r. Nr 82, poz. 599. 
pkt 16 przepisów wprowadzających stanowil, że pozostały w mocy przepisy ustaw szczególnych dotyczące wypowiadania i rozwiązywania umów o pracę.

Poza tym zgodnie z art. 3 pkt 10 i 11 przepisów wprowadzających k.z. w mocy pozostały ustawy o umowie o pracę poszczególnych kategorii pracowników, o pośrednictwie pracy i ochronie pracy oraz o załatwianiu zatargów zbiorowych między pewnymi kategoriami pracodawców i pracowników. Ponadto w art. 10 przepisów wprowadzających k.z. zastrzeżono, że przepisów art. 458 i 459 k.z. nie stosuje się do pracowników umysłowych objętych rozp. o um. o pr. prac. um., robotników objętych rozp. o um. o pr. rob., do pracowników pracujących na statkach morskich oraz robotników portowych w Gdyni, do pracowników podlegających ubezpieczeniu i do pracowników objętych układami zbiorowymi ${ }^{10}$. Wobec tych postanowień przepisy k.z. miały zastosowanie, jedynie jeśli dana sprawa nie była w nich unormowana. Odgrywały one rolę norm prawnych uzupełniających lub wspomagających (iuris supplendi vel adiuvandi causa), a nie norm poprawiających lub zmieniających (iuris corrigendi vel mutandi causa). W związku z tym przepisy k.z. w zakresie umowy o pracę odnośnie do dwóch podstawowych kategorii pracowników, czyli pracowników umysłowych ${ }^{11}$ oraz robotników ${ }^{12}$, miały właśnie charakter posiłkowy ${ }^{13}$. Zatem przepisy k.z. dotyczyły tylko nauczycieli

10 L. Domański, Zbieg przepisów kodeksu zobowiązań o umowie o pracę z przepisami ustaw szczególnych, „Nowy Kodeks Zobowiązań” 1935, nr 45-48, s. 149-151. Por. S. Grzybowski, Wstęp do nauki prawa pracy, Kraków 1947, s. 68-69; T. Dorożała, Prawa pracowników w świetle kodeksu zobowiąań, „Notarjat-Hipoteka” 4, 1934, nr 25,, s. 234.

11 Katalog pracowników umysłowych został podany w art. 2 rozp. o um. o pr. prac. um., stosując przy tym system enumeracyjny, który wyczerpująco wyliczał pracowników podlegających rozporządzeniu, uwzględniając głównie stanowisko zajmowane przez pracownika oraz charakter świadczonej pracy. Rozporządzenie o um. o pr. prac. um. przewidywało również w art. 3 możliwość dodania $\mathrm{w}$ drodze rozporządzenia do pracowników umysłowych kolejnych grup pracowniczych niewymienionych w art. 2 (skorzystał z tego Minister Opieki Społecznej, wydając w porozumieniu z Ministrem Komunikacji rozporządzenie z dnia 21 sierpnia 1934 roku o zaliczeniu nawigatorów i pilotów statków powietrznych do kategorii pracowników umysłowych, Dz.U. z 1934 r. Nr 78, poz. 729). Natomiast art. 4 wykluczał trzy grupy z pojęcia pracowników umysłowych, które w przeciwieństwie do grup niezaliczonych w art. 2 nie mogły być wciągnięte w drodze rozporządzenia przewidzianego $\mathrm{w}$ art. 3. Byli to uczniowie i praktykanci, osoby zatrudnione na statkach morskich oraz osoby zatrudnione w urzędach i instytucjach państwowych lub samorządowych, zob. Ł. Baszak, Regulacje prawne pracowników umystowych..., s. 13-14.

$12 \mathrm{~W}$ art. 2 rozp. o um. o pr. rob. występuje definicja robotnika, która w przeciwieństwie do definicji pracownika umysłowego była definicją negatywną. Wymienione w nim zostały grupy pracowników, którzy nie byli robotnikami. Przepisom rozp. o um. o pr. rob. nie podlegali więc pracownicy umysłowi, a także robotnicy będący robotnikami rolnymi, osobami zatrudnionymi w urzędach państwowych i komunalnych oraz w szkołach państwowych, a pełniące czynności analogiczne do czynności niższych funkcjonariuszy państwowych (gońce, woźni itp.), służbą domową i dozorcami domowymi. Za robotników nie byli również uważani chałupnicy (nie byli zatrudniani na podstawie umowy o pracę), uczniowie (zgodnie z art. 477 k.z. zawierali umowę o naukę, a nie umowę o pracę) oraz robotnicy portowi, zob. Ł. Baszak, Regulacje umowy o pracę robotników..., s 13-14.

13 L. Górnicki, Zasada uspołecznienia pewnych stosunków umownych w kodeksie zobowiąań z 1933 roku, [w:] Zasady prawne w dziejach prawa publicznego i prywatnego, red. M. Podkowski, 
domowych, służby domowej, a częściowo również dozorców domowych ${ }^{14}$ i robotników rolnych ${ }^{15}$, których stosunek pracy normowały układy zbiorowe pracy lub orzeczenia Komisji Rozjemczych. Jednak w wypadku służby domowej należy zaznaczyć, że przepisy k.z. w zakresie umowy o pracę nie obowiązywały na całym obszarze Rzeczypospolitej ${ }^{16}$. W niektórych dzielnicach obowiązywały one jedynie subsydiarnie w stosunku do przepisów pozaborowych ${ }^{17}$.

Umowa o pracę została uregulowana w k.z. w sposób całościowy, bez względu na rodzaj wykonywanej pracy, mając na celu ujednolicenie stosunków pracy na całym obszarze państwa. Przepisy dotyczące umowy o pracę znajdujące się w k.z. odznaczały się nowoczesnym charakterem odpowiadającym ówczesnym tendencjom rozwojowym. W postanowieniach regulujących umowę o pracę można także zaobserwować tak zwaną socjalizację prawa prywatnego ${ }^{18}$. W niniejszej pracy przeanalizuję przepisy dotyczące obowiązków stron, biorąc pod uwagę wskazane cechy charakteryzujące umowę o pracę w k.z. oraz ich stosunek do przepisów szczególnych, opierając się na poglądach doktryny i orzecznictwa.

Wrocław 2015, s. 162; R. Longchamps de Bérier, Kodeks zobowiazań a dotychczasowe prawo pracy, „Nowy Kodeks Zobowiązań” 1934, nr 9, s. 33-35; S.M. Grzybowski, Prawo pracy, „Współczesne Polskie Prawo Prywatne" 1948, z. 8, s. 8-9; H. Fisch, Problem socjalny w polskim kodeksie zobowiązań, „Nowy Kodeks Zobowiązań” 1935, nr 11, s. 42.

14 Dozorcy domowi podlegali ustawie z 23 stycznia 1920 roku o rozszerzeniu działania przepisów ustawy o załatwianiu zatargów zbiorowych pomiędzy pracodawcami a pracownikami rolnymi na zatargi zbiorowe między właścicielami nieruchomości miejskich a dozorcami domowymi (Dz.U. z 1920 r. Nr 8, poz. 53), ustawie z 16 maja 1922 roku (Dz.U. z 1922 r. Nr 39, poz. 324) w przedmiocie powołania Nadzwyczajnej Komisji Rozjemczej do załatwiania zatargów zbiorowych pomiędzy właścicielami nieruchomości miejskich a dozorcami domowymi oraz ustawie z 5 marca 1934 roku o załatwianiu zatargów zbiorowych pomiędzy właścicielami nieruchomości miejskich a dozorcami domowymi w woj. poznańskim (Dz.U. z 1934 r. Nr 26, poz. 198), zob. Z. Fenichel, Prawo pracy. Komentarz, Kraków-Warszawa 1939, s. 342.

${ }^{15} \mathrm{~W}$ wypadku pracowników rolnych (czeladzi) obowiązywały przepisy dzielnicowe z zastrzeżeniem, że dla pracowników rolnych nie wydano w danej kwestii orzeczenia Nadzwyczajnej Komisji Rozjemczej, która określała na konkretnym obszarze na dany rok warunki pracy i płacy; szerzej o robotnikach rolnych zob. A. Ajnenkiel, Położenie prawne robotników rolnych $w$ Polsce (1918-1939), Warszawa 1962; Z. Fenichel, Prawo pracy pracowników rolnych w Polsce, [w:] idem, Polskie prawo prywatne i procesowe, s. 371-383.

16 Służba domowa podlegała w byłej dzielnicy rosyjskiej rozdziałowi IX ustawy z dnia z 24 maja 1860 roku o sądach wiejskich w Królestwie Polskim (Dz.Pr. t. 57, nr 172), w byłej dzielnicy austriackiej regulaminom dla sług ogłoszonych: dla byłego okręgu administracyjnego krakowskiego rozporządzeniu rządu krajowego z dnia 11 marca 1855 roku (Dz.U. kr. okr. krak. $\mathrm{Nr}$ 14, oddz. II, 3), dla okręgu administracyjnego lwowskiego rozporządzeniu namiestnika z 1 lipca 1857 roku (Dz.U. kr. lwow. okr. Nr 12, oddz. II, 3), miasto Kraków — rozporządzeniu rządu krajowego z 4 lipca 1857 roku (Dz.U. krak. okr. Nr 18, oddz. I), zob. I. Rosenblüth, Encyklopedia..., s. $1690-1691$.

17 M. Święcicki, Instytucje polskiego prawa pracy w latach 1918-1939, Warszawa 1960, s. 148; tam też szerzej o projekcie ustawy o umowie o pracę służby domowej, który ostatecznie nie wszedł w życie, s. 148-150.

18 L. Górnicki, op. cit., s. 161-165.

Prawo 325, 2018

(C) for this edition by CNS 


\section{Postanowienia ogólne}

Umowa o pracę w k.z. została uregulowana w dziale I tytułu 11, w którym unormowano umowy o świadczenie usług ${ }^{19}$. W rozdziale I znalazły się przepisy ogólne (art. 441-446 k.z.), w rozdziale II przepisy dotyczące obowiązków stron (art. 447-465 k.z.), w rozdziale III zakończenia stosunku pracy, w rozdziale IV przejście zakładu pracy na inną osobę, a w rozdziale $\mathrm{V}$ przepisy regulujące umowę o naukę.

Umowa o pracę była umową konsensualną, dwustronną, wzajemną i pod tytułem obciążającym. Zgodnie z art. 441 k.z. pracownik zobowiązywał się do pełnienia dla pracodawcy pracy za wynagrodzeniem ${ }^{20}$. W umowie o pracę można było określić rodzaj i rozmiar pracy oraz rodzaj, wysokość i sposób wypłaty wynagrodzenia. Jednak postanowienia umowy nie mogły być sprzeczne $\mathrm{z}$ bezwzględnie obowiązującymi przepisami ustaw szczególnych, z przepisami k.z. ani z korzystniejszymi dla pracownika postanowieniami układu zbiorowego. Ustawy szczególne mogły wprowadzać pewne ograniczenia co do czasu i miejsca pracy oraz co do ochrony życia i zdrowia poszczególnych pracowników przed niebezpieczeństwem grożącym życiu i zdrowiu. Przepisy takich ustaw miały moc przepisów porządku publicznego, których indywidualna umowa nie mogła zmieniać. W samym k.z. występowały również przepisy bezwzględnie obowiązujące (były to art. $442 \S 1$, $444 \S 2,445 \S \S 2$ i 4, $460 \S 1,461 \S 3$ i 462 § 2), w stosunku do których postanowienia umowne nie mogły być przeciwne. W sytuacji gdy ani umowa indywidualna, ani układ zbiorowy nie określały rodzaju i rozmiaru pracy albo rodzaju i wysokości wynagrodzenia, pracownik zgodnie z art. 442 k.z. mógł żądać wynagrodzenia, jakie w danych okolicznościach było ustalone zwyczajem, a przy braku zwyczaju, jakie było uznane w danych okolicznościach za odpowiednie ${ }^{21}$.

Obowiązki pracownika i pracodawcy zostały w k.z. unormowane w rozdziale II działu I o umowie o pracę. Umowa o pracę była umową wzajemną, dlatego obowiązkowi jednej ze stron odpowiadało prawo drugiej strony. Zatem nie unormowano oddzielnie praw obu stron. Podstawowymi obowiązkami pracownika było pełnienie pracy i stosowanie się do poleceń pracodawcy. Natomiast pracodawca był przede wszystkim zobowiązany do zapłaty wynagrodzenia, udzielenia urlopu oraz pieczy w czasie choroby ${ }^{22}$.

19 Do umów o świadczenie usług zaliczono w k.z. oprócz umowy o pracę: umowę o dzieło, umowę o naukę, zlecenie, pośrednictwo, przechowanie, odpowiedzialność i prawo zastawu utrzymujących hotele, zajazdy i podobne zakłady, depozyt nieprawidłowy; o różnicach pomiędzy umową o pracę a umową o dzieło zob. S.M. Grzybowski, Wstęp do nauki prawa pracy, Kraków 1947, s. $95-101$.

${ }^{20}$ F. Zoll, Zobowiazania w zarysie wedtug polskiego kodeksu zobowiązań, Warszawa 1948, s. 373.

${ }^{21}$ L. Domański, Instytucje kodeksu zobowiąań. Część szczególna, Warszawa 1938, s. 361362; I. Rosenblüth, Prawo pracy..., s. 1700.

22 Z. Fenichel, Prawo pracy. Komentarz..., s. 65. 


\section{Obowiązki pracownika}

Podstawowym obowiązkiem pracownika, wynikającym $\mathrm{z}$ umowy o pracę w k.z. było pełnienie pracy (art. 441 k.z. ${ }^{23}$ ). Zgodnie z art. 447 k.z. ${ }^{24}$ pracownik zobowiązany był pełnić tę pracę osobiście, jeżeli z umowy lub okoliczności nie wynikało inaczej ${ }^{25}$. Zasadę tę thumaczono tym, że pracodawca zawierając umowę o pracę, kierował się zaufaniem do osobistych kwalifikacji pracownika. Nie miały tu zatem zastosowania przepisy art. 202 k.z., zgodnie z którym wierzyciel miał prawo żądać od dłużnika świadczenia osobistego tylko w przypadkach, w których wynika to z umowy albo z natury zobowiązania, i że zobowiązanie, które nie wymagało osobistego świadczenia dłużnika, mogło zostać wykonane przez osobę trzecią, nawet bez wiedzy dłużnika. Pracownik mógł skorzystać z zastępstwa, gdy zezwalała na to umowa o pracę lub pracodawca. Dopuszczalne było też zastępstwo czasowe, na przykład w czasie choroby pracownika, jeśli nie narażało to pracodawcy na uszczerbek. Jeżeli pracownik zlecił wykonanie czynności osobie trzeciej, pracodawca miał wtedy możliwość odstąpienia od umowy, uznając zachowanie pracownika za ważny powód (art. 470 k.z.). W przypadku zaś gdy pracownik wbrew zawartej umowie nie pełnił swoich obowiązków, odpowiadał wtedy, zgodnie z art. $471 \S 3$, jedynie za szkodę.

Kolejny obowiązek pracownika wynikał z $§ 1$ art. 448 k.z. ${ }^{26}$, zgodnie z którym pracownik miał swoją pracę pełnić sumiennie i ze starannością, jakiej wymaga rodzaj pracy lub zwyczaj oraz słuszny interes pracodawcy. Pod pojęciem sumienności rozumiano obowiązek lojalności pracownika (wierności). Wynikał on ze szczególnego rodzaju stosunku powstającego pomiędzy pracodawcą a pracownikiem, opartego na zaufaniu. Za naruszenie lojalności, oprócz niesumiennego pełnienia pracy, uznawano zdradzenie tajemnicy przedsiębiorstwa, niedozwoloną konkurencję, przyjmowanie od osób trzecich prowizji lub innego wynagrodzenia oraz popełnienie czynów przejawiających się jako nieuczciwa konkurencja albo nadużycie zaufania $^{27}$. Przepis ten rozwijał ogólne postanowienie wynikające z art. 189 k.z.,

23 Art. 441 k.z.: „Przez umowę o pracę pracownik zobowiązuje się do pełnienia dla pracodawcy pracy za wynagrodzeniem".

24 Przepis ten dotyczył również robotników i pracowników umysłowych ze względu na nieunormowanie tej kwestii w rozp. o um. o pr. prac. um. oraz rozp. o um. o pr. rob.

25 Źródłem tego przepisu był art. 168 projektu głównego: „W razie wątpliwości pracownik obowiązany jest pełnić usługi osobiście".

26 Źródłem przepisów art. 448 k.z. był art. 166 projektu głównego: „Pracownik winien pełnić pracę wiernie, dokładając staranności, wskazanej jej naturą lub zwyczajem i w tych granicach stosować się do poleceń pracodawcy. O ile z natury stosunku nie wynika nic innego, pracodawca może poruczyć nadzór innej osobie".

27 Zakaz konkurencji oraz zakaz przyjmowania bez zezwolenia pracodawcy wynagrodzenia od osób trzecich z tytułu pełnionych przez pracownika obowiązków dotyczył tylko pracowników umysłowych. W wypadku reszty pracowników czyny konkurencyjne pracownika mogły stanowić naruszenie obowiązku sumienności, co uzasadniało przedterminowe rozwiązanie umowy i obowią- 
według którego strony powinny wykonywać zobowiązanie zgodnie z jego treścią i w sposób odpowiadający wymaganiom dobrej wiary i zwyczajom uczciwego obrotu. Za brak lojalności uznawano na przykład podjęcie przez pracownika pracy, do której nie był przygotowany, lub pracę wykonał nieudolnie. Brak odpowiednich kwalifikacji zawodowych lub osobistych zgodnych z treścią zawartej umowy, wymaganiami dobrej wiary i zwyczajami uczciwego obrotu uprawniało pracodawcę na mocy $\S \S 1$ i 2 art. 470 k.z. do odstąpienia od umowy o pracę przez pracodawcę i przedwczesnego rozwiązania umowy. Pracownik miał swoją pracę pełnić ze starannością, jakiej wymaga rodzaj pracy lub zwyczaj oraz słuszny interes stron. Stopień wymaganej staranności zależał od rodzaju pracy. Inne wymagania były w stosunku na przykład do pracownika fizycznego, a inne do artysty. Zarówno pracownik, jak i pracodawca mogli powołać się na istnienie zwyczaju w razie sporu co do wymaganej staranności. Jednak decydującą rolę odgrywała w takich przypadkach opinia biegłych, względnie zeznania świadków. Pracownik powinien również pełnić pracę ze starannością ${ }^{28}$, jakiej wymaga słuszny interes pracodawcy. O stopniu staranności, jakiej wymagał słuszny interes pracodawcy, miał decydować według swojego słusznego uznania sąd. Brak staranności, jakiej wymagał rodzaj pracy lub zwyczaj albo słuszny interes pracodawcy, mógł być uznany za ważny powód, co uprawniało pracodawcę na mocy $\S \S 1$ i 2 art. 470 k.z. do odstąpienia od umowy o pracę i przedwczesnego rozwiązania umowy ${ }^{29}$.

Trzy kryteria sumienności i staranności, a więc rodzaj pracy lub zwyczaj oraz słuszny interes pracodawcy powinny być stosowane łącznie. Ustawodawca bowiem uwzględniał interes pracodawcy, dlatego w tym wypadku żądał od pracownika wyższej staranności, niż było to wymagane w zwykłym obrocie ${ }^{30}$.

W projekcie k.z. przewidziano art. $166^{31}$, który dotyczył sposobu naprawienia szkody wyrządzonej przez pracownika. Przepis ten został skreślony przez Komisję Kodyfikacyjną. W związku z tym w razie wyrządzenia szkody przez pracow-

zek naprawienia szkody według zasad ogólnych (art. 239 k.z.). R. Longchamps de Bérier, Polskie prawo..., Lwów 1938, s. 528; I. Rosenblüth, Prawo pracy, s. 1700.

28 Źródłem tego przepisu, który ostatecznie został przez Komisję Kodyfikacyjną uznany za zbyt kazuistyczny, był art. 165 projektu głównego: „Gdy z powodów nieprzewidzianych okaże się potrzeba pełnienia pracy ponad umówioną albo zwyczajem wskazaną miarę, pracownik obowiązany jest pełnić ją w miarę swoich sił. To samo obowiązuje, gdy chodzi o pełnienie pracy odmiennej od tej, do której się zobowiązał, jeżeli odmowa przedstawiałaby się jako sprzeczna z dobrymi obyczajami. W szczególności pracodawca może żądać pracy nadobowiązkowej, jeżeli taka praca okaże się potrzebną dla odwrócenia bezpośredniego niebezpieczeństwa grożącego ogółowi lub ruchowi przedsiębiorstwa oraz jeżeli chodzi o utrzymanie ruchu przedsiębiorstw ogólnej użyteczności. W przypadkach pełnienia pracy ponad umowę należy się pracownikowi wynagrodzenie dodatkowe z uwzględnieniem szczególnych okoliczności, wśród których pełnił tę pracę".

29 L. Domański, Instytucje..., s. 371-373.

30 Z. Fenichel, Prawo pracy. Komentarz..., s. 67.

31 Art. 166 projektu głównego: „Jeżeli pracownik wyrządzi z winy swej szkodę w narzędziach, maszynach lub materiałach, pracodawca winien dozwolić, by tę szkodę sam naprawił, o ile jest do tego zdolny, a to nie spowoduje znacznej przeszkody ruchu". 
nika w sposób rozmyślny, poprzez niedbalstwo lub nieostrożność, pracodawca mógł dochodzić od pracownika naprawienia szkody na zasadzie art. 239-242 k.z. Projekt przewidywał również art. $168^{32}$, który normował korzystanie przez pracownika z tajemnic przedsiębiorstwa po zakończeniu stosunku pracy. Został on także skreślony. Uznano, że taka sytuacja wymaga uregulowania w osobnych ustawach szczególnych ${ }^{33}$.

We wskazanych granicach na pracowniku spoczywał tak zwany obowiązek posłuszeństwa. Zgodnie z $§ 2$ art. 448 k.z. ${ }^{34}$ pracownik miał stosować się do poleceń pracodawcy lub ustanowionego przez pracodawcę kierownika, jeśli polecenia nie sprzeciwiały się umowie, ustawom i dobrym obyczajom. Jednak pracownik nie był zobowiązany spełniać innych czynności niż te, które wynikały z umowy, chyba że zachodziła nagła potrzeba. Pracownik nie musiał również wykonywać poleceń pracodawcy, jeśli sprzeciwiały się one ustawom, na przykład bezpodstawna praca $\mathrm{w}$ niedzielę, święta lub w godzinach nadliczbowych ${ }^{35}$. Pracownik miał prawo uchylić się też od wykonania polecenia pracodawcy, mimo iż miałoby ono związek $\mathrm{z}$ rodzajem pracy pracownika określonym w umowie, jeżeli polecenie to sprzeciwiałoby się dobrym obyczajom, na przykład danie komuś łapówki w imieniu pracodawcy. Pracodawca mógł wydawać polecenia osobiście bądź przez osoby, którym powierzył kierownictwo pracy. Jednak jeśli natura stosunku lub umowa na to nie pozwalała, pracodawca nie mógł poruczyć kierownictwa innej osobie. Taka sytuacja mogła mieć miejsce, na przykład gdy ktoś podjął pracę artystyczną pod kierunkiem pracodawcy, którego wskazówki mogły odpowiadać danemu artyście. Jeśli w takiej sytuacji pracodawca ustanowił kierownika, pracownik miał prawo odstąpić od umowy, jeżeli powód odstąpienia i przedwczesnego rozwiązania umowy mógł być uznany za ważny ( $\$ 2$ art. 470 k.z. $)^{36}$.

\section{Obowiązki pracodawcy}

Podstawowe obowiązki pracodawcy wynikające z przepisów k.z. dotyczących umowy o pracę wiązały się z wypłatą wynagrodzenia, przyzwoitym obchodzeniem się z pracownikiem i szanowaniem jego godności osobistej, pieczą nad

32 Art. 168 projektu głównego: „Pracownikowi wolno jest po skończeniu stosunku wytworzonego umową o pracę skorzystać z tajemnic przedsiębiorstwa, dostępnych mu w ciągu trwania stosunku, jeżeli od tego zależy pełne wykorzystanie jego zdolności zarobkowej, a nie wykracza przeciw obowiązującym ustawom o ochronie własności przemysłowej i o zwalczaniu nieuczciwej konkurencji”.

33 L. Domański, Instytucje..., s. 373-374.

34 Art. 448 k.z. miał zastosowanie do pracowników umysłowych (zbliżony był art. 3 rozp. o um. o pr. prac. um.), jednak nie dotyczył robotników ze względu na unormowanie tego zagadnienia w art. 6 rozp. o um. o pr. rob., J. Bloch, Kodeks pracy, Warszawa 1936, s. 171; Z. Fenichel, Prawo pracy. Komentarz..., s. 67.

35 Z. Fenichel, Prawo pracy. Komentarz..., s. 68.

${ }^{36}$ L. Domański, Instytucje..., 374-375. 
zdrowiem fizycznym i moralnym oraz z umożliwieniem pracownikowi znalezienia innej pracy po zakończeniu stosunku pracy.

Zgodnie z art. 449 k.z. pracodawca powinien przyzwoicie obchodzić się z pracownikiem i szanować jego godność osobistą (obowiązek ten był odpowiednikiem obowiązku posłuszeństwa i lojalności pracownika ${ }^{37}$. Pracodawca powinien zatem zachowywać się w stosunku do pracownika w sposób odpowiadający dobrym obyczajom i przyjętym zwyczajom. Jego zachowanie powinno być grzeczne i pomimo zależności pracownika od jego poleceń nie mogło uwłaczać godności osobistej pracownika ${ }^{38}$. Jeśli pracodawca naruszył ten obowiązek poprzez na przykład słowną lub czynną zniewagę, dopuszczenie się przez pracodawcę czynów nieobyczajnych wobec pracownicy itp., pracownik miał prawo do przedwczesnego rozwiązania umowy na mocy art. 470 k.z. ${ }^{39}$

Kolejne obowiązki pracodawcy wiązały się z wypłatą wynagrodzenia. Obowiązek wypłaty wynagrodzenia przez pracodawcę wynikał już z art. 441 k.z., który stanowił, że przez umowę o pracę pracownik zobowiązuje się do pełnienia dla pracodawcy pracy za wynagrodzeniem.

Zgodnie z art. 450 k.z. pracodawca zobowiązany był do dokonania wypłaty wynagrodzenia pieniężnego gotówką ${ }^{40}$. Jeżeli pracodawca wypłacił pracownikowi wynagrodzenie pieniężne wekslami, czekiem, bonami lub innymi rzeczami, odpowiadał wtedy za powstanie stąd szkody na podstawie art. 248 k.z. Pracodawca zobowiązany był wówczas do zapłaty odsetek zwłoki oraz do zapłaty innych powstałych szkód, które poniósł pracownik w związku z opóźnieniem wpływu gotówki, na przykład zapłata zaległości najmu lub innych zobowiązañ ${ }^{41}$. Przepis ten stanowił ius cogens, którego strony nie mogły zmienić w umowie. Ponadto pracodawca zmuszający pracownika do przyjęcia innej zapłaty niż gotówką, dopuszczał się wykroczenia $\mathrm{z}$ art. 59 rozporządzenia o wykroczeniach ${ }^{42}$.

Kolejny art. 451 k.z. regulował terminy płatności wynagrodzenia ${ }^{43}$. Zgodnie z $§ 1$ art. 451 k.z. termin płatności można było określić w umowie. Mamy tu

37 R. Longchamps de Bérier, Polskie prawo..., s. 530-535.

38 Według L. Domańskiego forma i stopień grzeczności wymaganej w stosunku do pracownika zależała od jego stanowiska społecznego i środowiska, w którym pracownik zazwyczaj przebywa, zob. idem, Instytucje..., s. 375.

39 J. Korzonek, I. Rosenblüth, Kodeks zobowiazań. Komentarz, Kraków 1936, s. 1099-1100.

40 Artykuł ten nie miał zastosowania do pracowników umysłowych i robotników ze względu na uregulowanie tej kwestii w art. 22 i 23 rozp. o um. o pr. rob. oraz w art. 13 rozp. o um. o prac. um.; tak uważali J. Bloch, op. cit., s. 172; Z. Fenichel, Prawo pracy. Komentarz..., s. 70. L. Domański dopuszczał zastosowanie art. 450 k.z. do pracowników umysłowych ze względu na brak sankcji w rozp. o um. o pr. prac. um., zob. idem, Instytucje..., s. 376.

41 I. Rosenblüth, Polskie prawo pracy, Kraków 1935, s. 120.

42 Z. Fenichel, Prawo pracy. Komentarz..., s. 70, J. Namitkiewicz, Kodeks zobowiązań. Komentarz, t. 2, Łódź 1949, s. 238.

43 Przepisy tego artykułu nie miały zastosowania ani do pracowników umysłowych, ani do robotników ze względu na unormowanie tej kwestii w art. 32 rozp. o um. o pr. rob. oraz w art. 15 rozp. o um. o pr. prac. um. 
więc do czynienia z przepisem ius dispositivum ${ }^{44}$. Strony mogły zatem dowolnie określić w umowie o pracę termin wypłaty wynagrodzenia, czyli mogło ono być wypłacane na przykład z góry. Jeśli termin ten nie był określony w umowie, stosowano wtedy zwyczaj. W wypadku zaś braku odmiennej umowy lub zwyczaju, zgodnie z $\S 2$ art. 451 k.z., pracodawca obowiązany był płacić pracownikowi $\mathrm{z}$ dołu. W przypadku wyznaczenia w umowie terminu miesięcznego lub krótszego okresu (krótszy od miesięcznego, a dłuższy od dniówkowego i obliczonego od godziny, na przykład okres tygodniowy) wypłata wynagrodzenia powinna nastąpić z końcem każdego okresu. Natomiast jeżeli w umowie oznaczono dłuższy okres (dłuższy niż miesięczny), wynagrodzenia należało wypłacić z końcem każdego miesiąca. $Z$ kolei wynagrodzenie dniówkowe albo obliczone od godziny i wynagrodzenie akordowe było płatne $\mathrm{z}$ końcem każdego tygodnia ${ }^{45}$. Zgodnie z $§ 3$ art. 451 k.z. w każdym z wymienionych przypadków wynagrodzenie powinno być płatne najpóźniej z chwilą zakończenia stosunku pracy ${ }^{46}$. W razie zwłoki z zapłatą pracodawca miał obowiązek zapłaty odsetek zwłoki (art. $248 \S 1$ k.z.) oraz wynagrodzenie wszelkich innych szkód (art. 248 § 3 k.z.). Zwłoka ta mogła stanowić ważny powód do odstąpienia od umowy (art. 470 k.z.) i pracodawcy groziła odpowiedzialność z art. 59 prawa o wykroczeniach. Roszczenie o wynagrodzenie przedawniało się po upływie trzech lat od daty płatności wynagrodzenia (art. 284 k.z.) ${ }^{47}$.

W kolejnych artykułach unormowane zostały dalsze kwestie związane z wynagrodzeniem. Według $\S 1$ art. 452 k.z. ${ }^{48}$, jeżeli pracownikowi zgodnie z umową oprócz stałego wynagrodzenia albo zamiast niego należał się udział w zysku pracodawcy (umowa tantiemowa), prowizja albo procenty ${ }^{49}$ od obrotu, produkcji, oszczędności lub podobne korzyści, pracodawca powinien dać pisemne obliczenie

$44 \mathrm{~W}$ przeciwieństwie do przepisów regulujących tę samą kwestię w wypadku pracowników umysłowych i robotników (art. 32 rozp. o um. o pr. rob. oraz w art. 15 rozp. o um. o pr. prac. um.).

45 Sposób obliczania terminów normowały art. 194-201 k.z.

46 Z. Fenichel, Prawo pracy. Komentarz..., s. 71-73.

47 J. Bloch, op. cit., s. 173.

48 Źródłem tego przepisu był art. 171 projektu głównego: ,Jeśli obok wynagrodzenia pieniężnego albo niezależnie od tego umówiono, że pracownikowi należy się udział w zysku pracodawcy (umowa tantjemowa), winien pracodawca udzielić pracownikowi albo wybranemu przez obie strony lub przez sędziego mężowi zaufania potrzebnych wyjaśnień, i o ile potrzeba sięokaże, dozwolić mu wglądu do ksiąg. Jeśli strony nie mogą się pogodzić co do tego, czy księgi ma przeglądać pracownik, czy mąż zaufania, rozstrzyga o tym sędzia. Jeśli strony nie mogą się zgodzić na osobę męża zaufania, mianuje go sędzia z pośród osób, wskazanych przez jedną i drugą stronę".

49 Umowa tantiemowa, czyli procentowo normowany udział w zysku czystym (netto); prowizja, czyli procentowo unormowany udział pracownika w przychodzie z poszczególnego interesu zdziałanego przy jego pomocy (np. pomocnicy handlowi, podróżujący, akwizytorzy); procenty od zysku, czyli procent od zysku brutto (zazwyczaj pracownicy na kierowniczych stanowiskach); procenty od obrotu pracownik pobiera bezpośrednio od klienta (np. kelnerzy, fryzjerzy), zob. Z. Fenichel, Prawo pracy. Komentarz..., s. 75-76. 
należności ${ }^{50}$. Wynagrodzenie tego typu mogło być żądane przez pracownika tylko w przypadku, gdy takie prawo wynikało z umowy ${ }^{51}$. Pracodawca był zobowiązany do obliczenia należności, jednak obowiązek ten nie dotyczył dostarczania pracownikowi wyciągu z ksiąg, odpisów dokumentów, korespondencji itp. W razie zwłoki w wydaniu pisemnego obliczenia pracownik mógł wytoczyć powództwo ze skutkami wynikającymi z art. 819 k.p.c. Zgodnie z § 2 art. 452 k.z. pracownik albo zamiast niego mąż zaufania, którego w braku zgody między stronami wyznaczał sąd, mógł w celu sprawdzenia obliczenia przejrzeć zapisy w księgach pracodawcy. Udziału w przejrzeniu ksiąg przez męża zaufania domagać się mógł zarówno pracownik uważający, że przejrzenia dokumentów powinien dokonać specjalista, jak i pracodawca, który obawiał się, że pracownik przy przeglądaniu ksiąg zapoznałby się z innymi informacjami. Przeciwko pracodawcy, który nie dopuścił pracownika albo męża zaufania do przejrzenia zapisów, pracownik mógł wytoczyć powództwo i dochodzić roszczenia z wyroku według art. 819 k.p.c. ${ }^{52}$ Przepis ten miał na celu pogodzenie interesów pracownika i pracodawcy. W interesie pracownika leżało bowiem zaznajomienie się z prawdziwym zyskiem. Natomiast pracodawcy zależało, aby nie ujawniano tajemnic przedsiębiorstwa ${ }^{53}$.

W myśl art. 453 k.z. ${ }^{54}$, jeżeli według umowy lub zwyczaju należała się pracownikowi gratyfikacja, a wynagrodzenie za pracę przypadało mu tylko za pewną część roku, należała mu się również stosunkowa część gratyfikacji i to samo obowiązywało w przypadku umowy tantiemowej. Gratyfikacje były dodatkowymi wynagrodzeniami obok pensji ze względu na powstałe okoliczności. Należały się nie tylko, jeśli były zapisane w umowie, lecz także wtedy, gdy był taki zwyczaj, na przykład z okazji świąt Bożego Narodzenia, Wielkiej Nocy, Nowego Roku, ukończenia bilansu rocznego, jak również w razie przedwczesnego rozwiązania umowy. W ostatnim wypadku wynagrodzenie było wypłacane za przepracowaną

50 Artykuł ten miał zastosowanie wobec robotników. Natomiast ze względu na unormowanie tej kwestii w art. 16 i 17 rozp. o um. o pr. prac. um. do pracowników umysłowych stosowano tylko $\S 2$ art. 452 k.z., zob. Z. Fenichel, Prawo pracy. Komentarz..., s. 74-75; odmiennego zdania był J. Bloch, op. cit., s. 173.

51 Sąd Najwyższy: ,przy umowach o pracę zwyczaj może być stosowany jedynie w przypadkach, przytoczonych w art. 442, 448, 451, 453 i 454; o tym, by można było za pomocą dowodu ze świadków stwierdzać istnienie zwyczaju płacenia pracownikowi odprawy w związku ze zwolnieniem go z pracy, przepisy k.z. milczą, gdy natomiast art. 453 k.z. wyraźnie podaje, że innego rodzaju świadczenie, a mianowicie gratyfikacja, może wypływać ze zwyczaju" (S.N. Zb. 433/37, C I 1749/36), cyt. za: J. Namitkiewicz, op. cit., s. 227; innego zdania był J. Bloch, op. cit., s. 173.

52 L. Domański, Instytucje ..., s. 380; Z. Fenichel, Prawo pracy. Komentarz..., s. 74-77.

53 Z motywów do art. 171 projektu części szczegółowej: „Przepis ten stara się pogodzić interes pracownika, któremu zależy na znajomości prawdziwego zysku, z interesem pracodawcy, by wglądanie osób trzecich w księgi nie przyniosło mu szkody przez ujawnienie tajemnic przedsiębiorstwa”, zob. E. Till, R. Longchamps de Bérier, Polskie prawo zobowiązań (część szczegółowa). Projekt wstępny z motywami, Lwów 1928, s. 182.

54 Przepis ten odpowiada przepisowi art. 12 rozp. o um. o pr. prac. um.; dotyczył również robotników, J. Bloch, op. cit., s. 174, L. Domański, Instytucje..., s. 381. 
część roku, na przykład jeżeli umowa o pracę rozwiązywała się po upływie czterech miesięcy, pracownikowi należały się cztery dwunaste części bilansowego, świątecznego, trzynastej pensji itp. ${ }^{55}$ Analogicznie stosowano postanowienia dotyczące tantiemy, czyli udziału w czystym zysku przedsiębiorstwa.

$\mathrm{W}$ art. 454 k.z. uregulowano termin płatności zasadniczych lub dodatkowych wynagrodzeń, których wysokość jest zmienna (zgodnie z art. 452 k.z. był to udział w zysku, prowizja lub procenty od obrotu) oraz wszelkiego rodzaju gratyfikacji. Zgodnie z art. 454 k.z., gdy obliczenie należności następuje na podstawie bilansu, wynagrodzenie należy wypłacić bezzwłocznie po jego ustaleniu. W innych przypadkach, przy braku odmiennej umowy lub zwyczaju, wypłata należności powinna nastąpić po upływie każdego miesiąca ${ }^{56}$.

$\mathrm{W}$ art. $455 \mathrm{k} . \mathrm{z}^{57}$ prawodawca nałożył na pracodawcę obowiązek wypłaty wynagrodzenia za pracę niespełnioną. Zgodnie z art. 455 k.z. ${ }^{58}$ pracownikowi należało się wynagrodzenie za pracę niespełnioną, jeżeli był gotów do jej pełnienia, a doznał przeszkody z przyczyn dotyczących pracodawcy. Gotowość pracownika do pełnienia pracy oznaczała domniemanie, że przeszkoda nastąpiła w trakcie pełnienia pracy. W wypadku gdy przeszkoda zaszła przed rozpoczęciem pracy, pracownik był zobowiązany do udowodnienia, że stawił się do pracy i nie mógł jej podjąć z powodu wystąpienia przeszkody. Przeszkoda z przyczyn dotyczących pracodawcy nie musiała być tylko wynikiem winy pracodawcy. Mogła również wynikać ze zdarzeń losowych lub siły wyższej (na przykład pęknięcie kotła w fabryce, choroba dziecka pracodawcy i niemożność udzielenia mu lekcji przez nauczyciela). Natomiast gdy przeszkoda w pracy wystąpiła wskutek nadzwyczajnych wypadków, przykładowo wojny, pożaru, wylewu rzeki, wtedy do umowy o pracę można było zastosować art. 269 k.z. Pracodawca powinien zawiadomić pracownika o ustaniu przeszkody. W tym czasie pracownik nie miał obowiązku starać się o inne zajęcie, chociażby pracodawca proponował mu takie rozwiązanie. Taki obowiązek nie wypływał ani z art. 455 k.z., ani z dobrych obyczajów lub zasad słuszności. Przyjmowano natomiast, że jeżeli pracownik wskutek przeszkody w pracy zaoszczędził pewne wydatki (na przykład przejazdy do pracy, narzędzia), to powinny być one potrącone $\mathrm{z}$ wynagrodzenia. $\mathrm{Z}$ wynagrodzenia

55 I. Rosenblüth, Polskie..., s. 125.

56 Przepis ten nie miał zastosowania do pracowników umysłowych, ze względu na ust. 2 art. 16 oraz art. 17 rozp. o um. o pr. prac. um.; dotyczył za to robotników, L. Domański, Instytucje..., s. 384.

57 Źródłem tego przepisu był ust. 1 art. 172 projektu głównego: „Także za pracę niespełnioną należy się pracownikowi wynagrodzenie, jeśli do jej pełnienia był gotów, a doznał przeszkody, z przyczyny, zachodzącej po stronie pracodawcy"; ust. 2 art. 172 został ostatecznie skreślony, a brzmiał następująco: „W takim przypadku pracownikowi można potrącić to, co oszczędził skutkiem niepełnienia usług, albo co zarobił, zajmując się czym innym, i to, czego zarobić rozmyślnie zaniechał".

58 Przepis art. 455 k.z. miał zastosowanie także do pracowników umysłowych i robotników, L. Domański, Instytucje..., s. 385; Z. Fenichel, Prawo pracy. Komentarz..., s. 81. 
potrącony powinien być również zarobek z innego źródła, osiągnięty dzięki przeszkodzie w pracy ${ }^{59}$. Przepis ten był wynikiem zasady, że każdy powinien ponosić ryzyko wypadków, jakie mu się zdarzają. Z samej treści i celu tego przepisu wynikało, że przepis ten był przepisem ius cogens, a więc strony nie mogły uchylić go w drodze umowy ${ }^{60}$.

W k.z. uregulowane zostało także wynagrodzenie akordowe (art. 456 k.z. ${ }^{61}$ ), które polegało na tym, że jego wysokość całkowicie lub częściowo zależała od wyniku pracy (na przykład od ilości wykopanego węgla, ilości wyprodukowanych sztuk). Wynagrodzenie akordowe zbliżało umowę o pracę do umowy o dzieło. Umowa o pracę różniła się od umowy o dzieło momentem zależności przy technicznym wykonywaniu pracy. Przy umowie o pracę pracownik wykonywał pracę pod nadzorem i kierownictwem pracodawcy, a przyjmujący zamówienie na dzieło wykonywał je samodzielnie ${ }^{62}$. W umowie o dzieło chodzi nie o pracę jako taką, którą ma się wypełniać dla drugiej osoby, lecz o rezultat ściśle w umowie o dzieło określony ${ }^{63}$. Zgodnie z $§ 1$ art. 456 k.z. ${ }^{64}$ pracownik, który zobowiązał się pełnić pracę na czas oznaczony lub nieoznaczony za wynagrodzeniem akordowym, mógł się domagać od pracodawcy dostarczenia mu pracy odpowiedniej co do rodzaju i rozmiarów. Za pracę odpowiednią co do rodzaju i rozmiarów rozu-

59 Za takim rozwiązaniem, mimo uchylenia ust. 2 art. 172 projektu głównego (zob. wyżej), opowiadała się większość przedstawicieli doktryny, zob. L. Domański, Instytucje..., s. 385; I. Rosenblüth, Polskie..., s. 126; Z. Fenichel, Prawo pracy. Komentarz..., s. 84-85, J. Bloch, op. cit., s. 175; odmiennego zdania był L. Peiper, Kodeks zobowiązań z dnia 27 października 1933, Dz.U. 82, poz. 598, tudzież przepisy wprowadzajace tenże kodeks z dnia 27 października 1933, Dz.U. 82, poz. 599: wraz z motywami referentów komisji kodyfikacyjnej oraz orzecznictwem polskiem, austrjackiem, francuskiem, niemieckiem i rosyjskiem, Kraków 1934, s. 626.

60 L. Domański, Instytucje ..., s. 384-385; Z. Fenichel, Prawo pracy. Komentarz..., s. 81-85; J. Basseches, I. Korkis, Kodeks zobowiązań. Przepisy wprowadzające kodeks zobowiąań, Lwów 1934, s. 185; J. Bloch, op. cit., s. 175.

61 Art. 456 k.z. miał zastosowanie także do pracowników umysłowych i robotników, J. Bloch, op. cit, s. 175.

62 J. Korzonek, I. Rosenblüth, op. cit., s. 1105-1106.

63 J. Górski, Umowa o pracę a zlecenia w świetle nauki i judykatury, „Głos Prawników Śląskich" 1, r. 3, 1939, s. 25; tam też szerzej o różnicach między umową o pracę a umową zlecenia w wyrokach Najwyższy Trybunał Administracyjny oraz Sądu Najwyższego, która polegała na tym, że o ile NTA cechy charakterystycznej umowy o pracę dopatruje się w osobistym podporządkowaniu się pracownika pracodawcy, o tyle SN cechy tej dopatruje się w odstąpieniu, w odpłatnym pozbyciu się przez pracownika oznaczonej ilości pracy w taki sposób, że pracodawca tą oznaczoną ilością pracy nabytą od pracownika może swobodnie dysponować w granicach umowy i ustawy, natomiast samego podporządkowania się pracownika pracodawcy nie uważa za moment decydujący.

64 Źródłem tego przepisu był art. 173 projektu głównego: „Pracownik, który zobowiązał się pełnić pracę przez pewien czas wyłącznie dla jednego pracodawcy za wynagrodzeniem od sztuki (praca akordowa), wymagać może, aby pracodawca, o ile nie dostarczy mu pracy, odpowiedniej jego uzdolnieniu, wypłacił mu odpowiednie wynagrodzenie na czas, za którym pracownik był gotów do pracy. Wysokość tego wynagrodzenia oznaczy w razie sporu sędzia. Pracodawca może w razie, gdy zabraknie pracy akordowej, zastąpić ją czasową". 
miano pracę, która w wyniku mogła dać dzieło, za które pracownik miał otrzymać wynagrodzenie akordowe. O tym, jaka praca była odpowiednia co do rodzaju i rozmiaru, decydowała treść umowy, zwyczaj lub przyjęty sposób wykonywania pracy (na przykład zgodnie z umową pracodawca zobowiązany był dostarczyć pracownikowi odpowiednią ilość materiałów, narzędzi niezbędnych do wykonania dzieła). Zgodnie z $§ 2$ art. 456 k.z., jeżeli pracodawca nie dopełnił tego obowiązku, pracownik mógł żądać stosownego wynagrodzenia za czas, w którym był gotów do pracy ${ }^{65}$. Co do gotowości do pracy, to należało ją rozumieć zgodnie z motywami w projekcie k.z. ${ }^{66}$, tak jak to miało miejsce przy analizie art. 455 k.z. $\mathrm{Za}$ stosowne uznawano wynagrodzenie odpowiadające temu, jakie pracownik uzyskałby, normalnie pracując. Żądanie wynagrodzenia było uwarunkowane wcześniejszym domaganiem się od pracodawcy dostarczenia pracy odpowiedniej co do rozmiaru i rodzaju. Gdyby pracodawca dostarczył pracownikowi pracę odpowiednią za stałym wynagrodzeniem zamiast wynagrodzenia akordowego, pracownik nie mógł żądać stosownego wynagrodzenia za czas, w którym był gotów do pracy, lecz mógłby odstąpić od umowy o pracę na zasadzie art. 470 k.z., jeżeli można było uznać przejście od wynagrodzenia akordowego do wynagrodzenia stałego (na przykład gdyby wynagrodzenie stałe nie odpowiadało przeciętnym zarobkom pracownika za wynagrodzenie akordowe) ${ }^{67}$.

Zgodnie z art. 457 k.z. ${ }^{68}$ pracodawca zobowiązany był również do zapłacenia wynagrodzenia przed terminem płatności za pracę już spełnioną pracownikowi znajdującemu się w potrzebie, jeżeli mógł to uczynić bez szkody dla siebie. Potrzeba pracownika mogła wynikać na przykład z powodu nagłej choroby pracownika lub członka jego rodziny, nieszczęśliwego wypadku, zwiększonych wydatków na dzieci w związku z początkiem roku szkolnego itp. Pracownik mógł

65 SN: „Okoliczność, iż wynagrodzenie oblicza się według ilości wykonanej pracy, nie zaś wedle czasu jej trwania, nie odbiera umowie (o akord) cech umowy o pracę. Umowa o akordowe wynagrodzenie za wydobywany z cudzego kamieniołomu kamień jest umową o pracę, nie zaś umową o dzieło lub umową o kupno kamienia. Jeżeli pracodawca nie zastrzegł w umowie inaczej, łączenie się robotników akordowych w dowolne grupy nie pozbawia pracy cech pracy akordowej" (C II. 2157/37, P.P.P. z r. 1939, Nr I, s. 30).

66 Z motywów do art. 173 projektu części szczegółowej: „Przepis ten jest odpowiedniem zastosowaniem zasady art. 172 do pracy czasowo akordowej, t. j. z umowy zawartej na pewien czas z obliczeniem od sztuki. Przy tego rodzaju pracy pracownik, który pracuje wyłącznie dla jednego pracodawcy, byłby skrzywdzony, gdyby nie miał pracy, zapełniającej mu cały czas, w którym pozostaje do dyspozycji pracodawcy. Za wzorem art. 331 pr. szwajc. nakłada więc projekt na pracodawcę obowiązek dostarczania mu dostatecznej pracy albo wynagrodzenia za czas, w którym pracownik był do dyspozycji, w miarę ilości roboty, którą byłby mógł wykonać, gdyby mu jej dostarczono. Nie można tego nazwać odszkodowaniem, gdyż należy się ono nawet bez winy pracodawcy. Zapobiega to też faworyzowaniu jednych z krzywdą drugich”. Zob. E. Till, R. Longchamps de Bérier, op. cit., s. $182-183$.

${ }^{67}$ L. Domański, Instytucje..., s. 386-388; J. Bloch, op. cit., s. 175.

68 Art. 457 k.z. miał zastosowanie także do pracowników umysłowych i robotników, L. Domański, Instytucje..., s. 389; Z. Fenichel, Prawo pracy. Komentarz..., s. 86; J. Bloch, op. cit., s. 176. 
domagać się wynagrodzenia tylko za pracę spełnioną, a więc na przykład jedenastego dnia miesiąca mógł żądać zaliczki w wysokości jednej trzeciej części wynagrodzenia. Jednak nie zabraniało to wypłaty przez pracodawcę zaliczki za pracę niespełnioną. Pracodawca mógł sprzeciwić się wypłacie zaliczki, jeżeli udowodnił, że wypłata zaliczki mogłaby wyrządzić mu szkodę (na przykład dla wypłaty zaliczki potrzebowałby zaciągnąć kredyt). Zaliczka nie podlegała oprocentowaniu, ponieważ była wypłacana za pracę już wykonaną. Jeżeli pracodawca bez usprawiedliwienia odmówił wypłaty wynagrodzenia za pracę spełnioną, ponosił odpowiedzialność za szkody poniesione wskutek tego przez pracownika (na podstawie art. 239-242 k.z. w związku z art. 60 k.z.) ${ }^{69}$.

Kolejne obowiązki pracodawcy dotyczyły wypłaty wynagrodzenia za pracę niespełnioną z powodu przeszkody w jej pełnieniu z przyczyn leżących po stronie pracownika (art. 458 i 459 k.z. ${ }^{70}$ ). Prawo do wynagrodzenia za pracę niespełnioną z powodu przeszkód, które wyniknęły z przyczyn dotyczących pracownika, było uzależnione od kilku warunków. Zgodnie z $\S 1$ art. 458 k.z. ${ }^{71}$ pracownik, dla którego stosunek pracy stanowił wyłączne lub główne źródło utrzymania, zachowywał prawo do wynagrodzenia, chociażby w pełnieniu pracy doznał bez swej winy przeszkody skutkiem choroby, wypadku, powołania go na ćwiczenia woskowe albo z innych podobnych ważnych przyczyn. Dochód z pracy nie mógł być zatem ubocznym źródłem utrzymania, a za inne ważne podobne przyczyny uznawano np. przerwanie komunikacji, chorobę lub śmierć osoby bliskiej, wyjazd na pogrzeb najbliższych krewnych, powołanie na przysięgłego, biegłego lub świadka itd. Jeżeli jednak pracownik spowodował przeszkodę w pracy rozmyśl-

69 J. Namitkiewicz, op. cit., s. 244-245; L. Domański, Instytucje..., s. 388-389.

70 Zgodnie z $\S 1$ i 2 art. 10 przepisów wprowadzających k.z. przepisów art. 458 i 459 k.z. nie stosowano do pracowników umysłowych (objętych rozp. o um. o pr. prac. um.), robotników (objętych rozp. o um. o pr. rob.), pracowników zatrudnionych na statkach morskich oraz robotników portowych w Gdyni oraz pracowników podlegających obowiązkowi ubezpieczenia (określonego w ustawie z dnia 28 marca 1933 roku o ubezpieczeniu społecznym, Dz.U. R.P. Nr. 51, poz. 396) oraz pracowników objętych układami zbiorowymi; co do pracowników umysłowych, w miejsce art. 458 i 459 k.z. stosowano art. 19 i 20 rozp. o um. o pr. prac. um.

71 Źródłem przepisów art. 458 k.z. był ust. 1 art. 174 oraz art. 175 projektu głównego: 1) ust. 1 art. 174: „W stosunku zawartym na czas dłuższy, albo za dłuższym wypowiedzeniem, gdy stosunek trwa już najmniej pół roku, pracownik, którego utrzymanie polega wyłącznie albo przeważnie na pracy, umową zapewnionej, zachowuje prawo do wynagrodzenia, chociażby w pełnieniu usług doznał bez winy swej przeszkody skutkiem nieprzewidzianej przy zawiązaniu stosunku choroby albo skutkiem obowiązkowej służby w wojsku polskim, albo z innych ważnych, od niego niezależnych, a jego osoby dotyczących przyczyn, a to przez czas najwyżej czterech tygodni”; 2) art. 175: „Wynagrodzenie za czas niepełnienia pracy, skutkiem przeszkody w jego osobie, należy się pracownikowi, chociażby stosunek pracy skończył się przed ustaniem przeszkody, względnie przed upływem czterech tygodni od dnia jej zaistnienia. Prawo to ustaje jednak wcześniej, z chwilą gdy stosunek skończy się skutkiem upływu czasu, na jaki został pierwotnie zawarty, skutkiem wypowiedzenia, dokonanego przed zaistnieniem przeszkody oraz skutkiem wydalenia pracownika, niespowodowanego przeszkodą". 
nie lub przez niedbalstwo, a więc na przykład uległ chorobie z własnej nieostrożności z powodu rozwiązłego życia, nadużywania alkoholu, wtedy pozbawiony był możliwości żądania wynagrodzenia za pracę niespełnioną ${ }^{72}$. Prawodawca przy tworzeniu tych przepisów kierował się względami humanitarnymi, przenosząc niebezpieczeństwo na pracodawcę ${ }^{73}$.

Zgodnie z § 2 art. 458 k.z., jeżeli ustawa lub umowa nie zawierały postanowień korzystniejszych dla pracownika, prawo żądania wynagrodzenia za pracę niespełnioną służyło pracownikowi tylko przez dwa tygodnie i jedynie wówczas, gdy stosunek pracy trwał już pół roku przed powstaniem przeszkody. Okres dwóch tygodni niespełniania pracy powinien być ciągły, bez przerw, które mogłyby go wydłużyć. Skrócenia tego okresu nie można było dokonać umownie ze względów humanitarnych, w celu zapewnienia pracownikowi środków utrzymania. Dekret Prezydenta Rzeczypospolitej z dnia 30 sierpnia 1939 roku zmieniał art. 457 k.z., dodając, że w wypadku powołania pracownika na ćwiczenia wojskowe prawo żądania wynagrodzenia za pracę niespełnioną służyło pracownikowi bez względu na czas trwania stosunku pracy przed powołaniem na te ćwiczenia ${ }^{74}$. Wedle $\S 3$

72 L. Domański, Instytucje..., s. 386-390; Z. Fenichel, Prawo pracy. Komentarz..., s. 86-87; J. Namitkiewicz, op. cit., s. 244-245; L. Peiper, op. cit., s. 632.

73 Z motywów do art. 174 i 175 projektu części szczegółowej: „Z zasady ogólnej, że każdy powinien ponosić następstwa przypadku, który się zdarzył w jego osobie lub majątku, oraz artykułów 172 i 173 a contrario wynika, że niebezpieczeństwo przypadków, które dotyczą osoby pracownika, ponosi pracownik t. zn. traci za czas przerwy prawo do wynagrodzenia. W drodze jednak wyjątku od tej reguły artykuł 174, za wzorem nowszych ustawodawstw (§ $616 \mathrm{~K}$. n., § 1154 b K. a., a 335 pr. szwajc.), pozostawiając w pewnym zakresie pracownikowi prawo do wynagrodzenia za czas przerwy spowodowanej takim przypadkiem, przenosi periculum na pracodawcę. Motywowane jest to względami humanitarnemi, gdyż pracownik, którego utrzymanie polega całkowicie albo przeważnie na pracy (fizycznej czy umysłowej), byłby w razie przeszkody pozbawiony utrzymania. Nie można jednak zamykać oczu na to, że postanowienie wydane w interesie pracownika a zapewniające mu pobory nawet w przypadkach przerwy pracy, jest, zwłaszcza dla pracodawców drobnych, jak np. rzemieślników o jednym tylko pomocniku, bardzo uciążliwe. Zakład np. fabryczny zatrudniający większą ilość pracowników, łatwiej zniesie ubytek jednego z nich, drobny przedsiębiorca traci siłę pomocniczą, a nie doznaje ulgi, musi opłacać zastępcę, a nie ma możności odbić tej straty podwyższeniem cen wytworu. Dlatego konieczne jest ograniczyć to prawo pracownika do minimum. Projekt więc przewiduje je tylko w stosunkach trwających już dłuższy czas, tylko przez okres najwyżej 4 tygodni i tylko w przypadkach prawdziwej konieczności tj. choroby, służby obowiązkowej w wojsku lub innych ważnych przyczyn. Przytem daje pracodawcy możność odzyskania przynajmniej w części doznanego ubytku”. E. Till, R. Longchamp de Bérier, op. cit., s. 183.

74 Dekret Prezydenta RP z 30 sierpnia 1939 roku o zmianie kodeksu zobowiązań oraz przepisów wprowadzających kodeks zobowiązań (Dz.U. z 1939 r. Nr 84, poz. 538, 539), który zmieniał $\S 2$ art. 458: „Jeżeli ustawa lub umowa nie zawiera korzystniejszych dla pracownika postanowień, prawo określone w paragrafie poprzedzającym służy mu przez okres dwóch tygodni wówczas, gdy stosunek pracy trwał już pół roku przed powstaniem przeszkody, a w przypadku powołania pracownika na ćwiczenia wojskowe - bez względu na czas trwania stosunku pracy przed powołaniem na ćwiczenia”; poza tym art. 2 ww. dekretu stanowił, że uprawnienie do wynagrodzenia z art. 458 k.z. przysługuje także pracownikom powołanym jako żołnierze rezerwy lub pospolitego ruszenia do czynnej służby wojskowej ze względu na bezpieczeństwo państwa. 
art. 458 k.z. wynagrodzenie to należało się pracownikowi nawet w sytuacji zakończenia stosunku pracy przed upływem dwutygodniowego terminu wskutek wypowiedzenia dokonanego w okresie przeszkody przez pracodawcę albo wskutek przedwczesnego rozwiązania umowy przez pracodawcę bez winy pracownika. Zgodnie z tym, jeżeli pracodawca wypowiedział umowę przed nastaniem przeszkody, pracownik zachowywał prawo do wynagrodzenia za pracę niespełnioną tylko do chwili rozwiązania umowy z upływem terminu wypowiedzenia ${ }^{75}$.

Zgodnie z art. 459 k.z., jeżeli stosunek pracy trwał mniej niż pół roku, pracownik zachowywał prawo do wynagrodzenia $\mathrm{w}$ razie niemożności pełnienia pracy z ważnej przyczyny przez krótki czas. Przepis tego artykułu dotyczył pracowników nieobjętych przepisami art. 458 k.z., czyli tych, których stosunek pracy trwał krócej niż pół roku. Okres, w ciągu którego pracownik nie mógł pełnić pracy, powinien być krótszy niż dwa tygodnie. Poza tą zmianą miały zastosowanie przepisy art. 458 k.z. Przepisy art. 458 oraz 459 k.z. miały charakter ochronny. Były zatem przepisami bezwzględnie obowiązującymi, wobec czego umowne skrócenie okresu przerwy było nieważne ${ }^{76}$. Należy jeszcze zaznaczyć, że na zasadzie art. 8 przepisów wprowadzających Kodeks zobowiązań, aż do wydania ustawy szczególnej o umowie o pracę nauczycieli, należało stosować przepisy k.z. Jednak przepis ten w stosunku do nauczycieli zatrudnionych w zakładach naukowych zmieniał postanowienia $\S 2$ art. 458 i art. 459 k.z. ${ }^{77}$ Natomiast postanowienia zawarte $\mathrm{w} \S \S 1$ i 3 art. 458 k.z. miały zastosowanie do nauczycieli zatrudnionych w zakładach naukowych ${ }^{78}$.

Zgodnie z $§ 1$ art. 460 k.z. ${ }^{79}$ zrzeczenie się z góry wynagrodzenia, przypadającego na czas przeszkody, jest nieważne ${ }^{80}$. Mowa jest tu o zrzeczeniu się przez

75 L. Domański, Instytucje..., s. 391-392.

76 J. Namitkiewicz, op. cit., s. 245-248.

77 Pkt 2 art. 8 przepisów wprowadzających k.z.: ,W razie niemożności pełnienia pracy z ważnej przyczyny nauczyciel zatrudniony w zakładzie naukowym zachowuje prawo do wynagrodzenia. Jeżeli umowa nie zawiera korzystniejszych dla nauczycieli postanowień, służy mu prawo do wynagrodzenia przez okres ustalony zwyczajem, a w braku zwyczaju przez okres trzech miesięcy".

78 L. Domański, Instytucje..., s. 392.

79 Przepis $\S 1$ art. 460 k.z. miał zastosowanie wobec pracowników umysłowych oraz robotników, zob. L. Domański, Instytucje..., s. 394; odmiennego zdania był J. Bloch, op. cit., s. 177-178.

${ }^{80}$ Zgodnie z art. 442 k.z.: „§ 1. Zrzeczenie się zgóry wynagrodzenia za pracę jest nieważne. $\S 2$. Jeżeli ani umowa indywidualna, ani układ zbiorowy nie określa rodzaju i rozmiaru pracy albo rodzaju i wysokości wynagrodzenia, można żądać pracy i wynagrodzenia, jakie w danych okolicznościach są ustalone zwyczajem, a w braku zwyczaju, jakie uchodzą za odpowiednie"; zrzeczenie się wynagrodzenia za pracę należy rozumieć w tym znaczeniu, że jeżeli pracownik zobowiązał się do pracy za wynagrodzeniem, to późniejsze zrzeczenie się z góry, czyli za czas jeszcze nieprzepracowany, było nieważne. Zatem jeżeli w treści umowy nie wspomniano o obowiązku pracodawcy wynagrodzenia pracownika za pracę, a okoliczności towarzyszące zawarciu umowy nie stwierdzają, żeby pracownik zobowiązał się do pełnienia pracy dla pracodawcy za wynagrodzeniem, należało wtedy przyjąć, że pracownik zobowiązał się pracować za darmo. Odrzucono więc domniemanie, że każde zobowiązanie się do pracy dla drugiego uznaje się za płatne, zob. L. Domański, Instytucje..., s. 360. 
pracownika wynagrodzenia za czas przeszkody. Przeszkodą w tym wypadku mogła być zarówno przeszkoda wynikająca z przyczyn dotyczących pracodawcy czy też pracownika. Zastosowanie w tym zakresie miały zarówno art. 458 i 459 k.z., jak i art. 455 k.z. ${ }^{81}$. Pracownik mógł jednak zrzec się wynagrodzenia po ustaniu przeszkody, jeżeli wynagrodzenie nie zostało mu jeszcze wypłacone. W przypadku wypłacenia wynagrodzenia pracownik mógł zgodzić się na zaliczenie go na poczet wynagrodzenia należnego za dalszą pracę, po ustaniu przeszkody, ponieważ $\S 1$ art. 460 k.z. tego nie zabrania8 ${ }^{82}$. Wedle $\S 2$ art. 460 k.z. ${ }^{83}$ pracodawca mógł odliczyć od przypadającego za czas przeszkody wynagrodzenia sumy ${ }^{84}$, które pracownik otrzymał za ten czas z funduszów publicznych, z wyjątkiem sum otrzymanych w czasie ćwiczeń wojskowych ${ }^{85}$. Było to prawo, którego pracodawca mógł się zrzec. Przez fundusze publiczne rozumiano nie tylko ubezpieczenia społeczne, lecz także przypadające z tytułu należności przysięgłego, świadka itp. Przepisy art. 460 k.z. miały również zastosowanie do nauczycieli zatrudnionych w zakładach naukowych, z wyłączeniem przepisów art. 458 i 459 k.z. jako sprzecznych z przepisami art. VIII pkt 2 przepisów wprowadzających k.z. ${ }^{86}$

Oprócz obowiązków związanych z wynagrodzeniem na pracodawcy ciążył obowiązek pieczy nad zdrowiem fizycznym i moralnym pracownika. Wynikało

81 Z. Fenichel, Prawo pracy. Komentarz..., s. 91; J. Namitkiewicz, op. cit., s. 249; odmiennego zdania był J. Bloch, który uważał, że art. 460 dotyczył tylko wynagrodzenia przypadającego na mocy art. 458 lub 459 k.z., zob. J. Bloch, op. cit., s. 177-178; pozostali autorzy, jak L. Domański, J. Korzonek, I. Rosenblüth, L. Peiper, nie ustosunkowali się wyraźnie co do stosowania postanowień art. 455 k.z. w stosunku do art. 460 k.z.

82 L. Domański, Instytucje..., s. 393-394; J. Korzonek, I. Rosenblüth, op. cit., s. 1110.

83 Przepis $\S 2$ art. 460 k.z. nie miał zastosowania do pracowników umysłowych ze względu na ust. 2 art. 19 rozp. o um. o pr. prac. um., miał natomiast zastosowanie wobec robotników, zob. L. Domański, Instytucje..., s. 394; odmiennego zdania był J. Bloch, który uważał, że przepisy art. 460 k.z. nie dotyczyły ani pracowników umysłowych, ani robotników, zob. J. Bloch, op. cit., s. $177-178$.

${ }^{84}$ Sumy, jakie pracownik otrzymywał z funduszów publicznych, wynikały z ustawy z dnia 28 marca 1933 roku o ubezpieczeniu społecznem (Dz.U. z 1933 r. Nr 51, poz. 396) oraz z art. 10 przep. wprow. k.z.

85 Z motywów do art. 174 i 175 projektu części szczegółowej: „Potrącenie kwot pobranych przez pracownika tytułem ubezpieczenia z kwoty wynagrodzenia jest tym bardziej uzasadnione, że możność pobierania $\mathrm{z}$ dwóch stron wynagrodzenia byłaby często zbyt silną pobudką do łatwego ociągania się do pracy. K. a. (§ 1154 b) pozwala potrącić tylko część odpowiadającą premji pracodawcy. Jest to kompromisowe załatwienie sprawy miedzy tymi, którzy pracodawcy chcieli odmówić praw potrącania w ogóle, a tymi, którzy pozwalali na całkowite potrącenie. To ostatnie jest jednak uzasadnione tem, że pracownik pobierając jedno i drugie, wzbogaciłby się w sposób nieusprawiedliwiony. Pracownik nie ma prawa do owych korzyści w przypadkach, w których względy humanitarne odpadają (choroba zawiniona życiem rozwiązłem, dobrowolne zgłoszenie się do służby wojskowej itp.), niemniej gdyby przeszkoda istniała już w czasie zawiązania stosunku albo była wówczas do przewidzenia”; E. Till, R. Longchamps de Bérier, op. cit., s. 183-184.

${ }^{86}$ L. Domański, Instytucje..., s. 394-395; Z. Fenichel, Prawo pracy. Komentarz..., s. 91-93, L. Peiper, op. cit., s. 633. 
to ze stosunku osobistego, jaki łączył pracodawcę i pracownika ${ }^{87}$. Zgodnie z § 1 art. $461 \mathrm{k.z} .{ }^{88}$ pracodawca powinien co do pomieszczeń i narzędzi, jakich dostarcza, poczynić odpowiednie zarządzenia w celu zabezpieczenia życia i zdrowia ${ }^{89}$. Przez pomieszczenia rozumiano sale i hale przemysłowe, lokale przemysłowo-handlowe, w których pracują pracownicy, a także ubikacje, szatnie itd. Pracodawca powinien dokładać wszelkich starań, aby w tych pomieszczeniach panowały odpowiednie warunki (odpowiednia ilość powietrza i światła, zachowana czystość itp.). Natomiast przez narzędzia rozumiano instrumenty ręczne, maszyny, rusztowania, drabiny itd. W celu zabezpieczenia życia i zdrowia pracownika pracodawca powinien w tym zakresie poczynić odpowiednie zarządzenia, które odpowiadały powszechnie wskazanym wytycznym ${ }^{90}$. W związku z tym, jeżeli obowiązywały odpowiednie przepisy ochronne, pracodawca powinien się do nich stosować ${ }^{91}$. Wedle $\S 2$ art. 461 k.z. pracodawca, jeżeli zobowiązał się dostarczać pracownikowi mieszkanie, nocleg lub żywność, powinien przy tych świadczeniach mieć na względzie zdrowie i przyzwoitość. Mowa tutaj o mieszkaniu przydzielonym tytułem uposażenia służbowego, a nie o mieszkaniu, za które pracownik płaci umówiony czynsz najmu. Pracodawca dostarczając pracownikowi mieszkanie, nocleg lub żywność, powinien mieć na względzie ogólne warunki zdrowotne (na przykład powinien baczyć, żeby dostarczana żywność była świeża i nieszkodliwa dla zdrowia ludzkiego w ogóle, a nie ze względu na szczególny stan zdrowia pracownika lub członka jego rodziny). Pracodawca powinien jeszcze mieć na wzglę-

87 R. Longchamps de Bérier, Polskie prawo..., s. 533; F. Zoll, op. cit., s. 381-382.

88 Art. 461 k.z. miał zastosowanie w stosunku do pracowników umysłowych, ale ze względu na art. 7 rozp. o um. o pr. prac. rob. nie obejmował robotników; przepisy art. 461 k.z. miały również zastosowanie do służby domowej wobec niezupełnego unormowania tej kwestii w art. 561 ustawy o sądach gminnych, z wyjątkiem Małopolski (wobec $\$ 20$ obowiązujących regulaminów z 1855 i 1857 roku), zob. J. Bloch, op. cit., s. 178; Z. Fenichel, Prawo pracy. Komentarz..., s. 93.

89 SN: „Pracodawca odpowiedzialny jest za nieszczęśliwy wypadek, jakiemu uległ małoletni pracownik podczas pełnienia pracy, nieodpowiadającej jego wiekowi pod względem bezpieczeństwa i bez nadzoru ze strony pracodawcy lub innej pełnoletniej osoby" (C. I. 606/38, N. K. Z. z 1938 r., Nr 51-52, s. 179), cyt. za: J. Namitkiewicz, op. cit., s. 250; „Art. 461 k.z., wkładający na pracodawcę obowiązek poczynienia odpowiednich zarządzeń celem zabezpieczenia życia i zdrowia pracownika przy dostarczaniu mu pomieszczeń i narzędzi, jako zawarty w dziale o umowie o pracę, nie ma zastosowania w przypadku istnienia umowy o dzieło. W szczególności więc nie dotyczy art. $461 \S 1$ tego, który zamówił naprawę rynny w swym domu, i w tym celu dostarczył rzemieślnikowi własną drabinę, zbyt słabą, z której przyjmujący zamówienie, spadł, doznając uszkodzenia ciała" (C. II. 3307/37, N. K. Z. z 1939 r., Nr 6, s. 19); „Nieopalenie lub nienależyte opalenie lokalu służbowego w porze zimowej, które spowodowało zaziębienie i śmierć pracownika skutkuje odpowiedzialność pracodawcy, chociażby nie było ono wyłączną przyczyną, lecz jednym z warunków powstałego skutku, bez którego skutek nie nastąpił" (SN Zb. Urz. 146/34), cyt. za: J. Bloch, op. cit., s. 178.

90 L. Domański, Instytucje..., s. 395; Z. Fenichel, Prawo pracy. Komentarz..., s. 93-93; L. Peiper, op. cit., s. 634.

91 Pracodawca w szczególności powinien się stosować do rozporządzenia Prezydenta Rzeczypospolitej z dnia 7 czerwca 1927 roku o prawie przemysłowym (Dz.U. z 1927 r. Nr 53, poz. 468) oraz z dnia 16 marca 1928 roku o bezpieczeństwie i higienie pracy (Dz.U. z 1928 r. Nr 35, poz. 325). 
dzie przyzwoitość, a mianowicie nie dopuszczać do spędzania nocy w jednym pomieszczeniu przez pracowników różnej płci. W razie poniesienia szkody przez pracownika wskutek uchybienia przez pracodawcę obowiązkom przewidzianym w $\S \S 1$ i 2 art. 461 k.z. pracownik miał możliwość dochodzenia szkody na podstawie art. 239-242 k.z., nie później jednak jak przed upływem roku od rozwiązania stosunku pracy (art. 473 k.z.) $)^{92}$. Pracodawca odpowiadał również $\mathrm{z}$ art. 152 n. k.z., z uwzględnieniem przepisu art. 196 ustawy o ubezpieczeniu społecznym (odnośnie do zakładów wprawianych w ruch za pomocą sił przyrody, na przykład pary, gazu, elektryczności, wody itp. $)^{93}$. W razie odmówienia wydania przez pracodawcę odpowiednich zarządzeń pracownik mógł wstrzymać się od pełnienia pracy na podstawie art. 215 n. k.z. ze skutkami z art. 455 k.z. ${ }^{94} \mathrm{~W}$ wypadku poważnego zagrożenia życia lub zdrowia pracownika z powodu uchybienia przez pracodawcę obowiązkom wynikającym z przepisów art. 461 k.z. pracownik mógł odstąpić od umowy z ważnego powodu, co skutkowało rozwiązaniem stosunku pracy (art. 470 k.z.). Zgodnie z $§ 3$ art. 461 k.z. nie można było w drodze umowy zmieniać ani ograniczać obowiązków pracodawcy przewidzianych w $\S \S 1$ i 2 art. 461 k.z.

Kolejne obowiązki pracodawcy związane pieczą nad zdrowiem i życiem pracownika zostały unormowane w art. 462 k.z. ${ }^{95}$, w którym zgodnie z $§ 1$ pracodawca miał obowiązek zapewnienia pracownikowi potrzebnego utrzymania i opieki lekarskiej oraz koniecznych środków leczniczych, gdy pracownik został przyjęty przez pracodawcę w poczet domowników i uległ chorobie niespowodowanej przezeń rozmyślnie, oraz gdy stosunek pracy stanowił wyłączne lub główne źródło utrzymania. W poczet domowników zaliczano służbę domową, nauczycieli, wychowawców itp., za domowników też uważano takich pracowników, którzy mieszkają razem z pracodawcą i są na jego utrzymaniu. Pracodawca miał spełnić te obowiązki w ciągu dwóch tygodni, jeżeli stosunek pracy trwał już dwa tygodnie, a w ciągu czterech tygodni, jeżeli stosunek pracy trwał już pół roku. Zgodnie z $\S 2$ art. 462 k.z. zrzeczenie się tych praw z góry było nieważne. Wedle $\S 3$ art. 462 k.z. pracodawca mógł potrącić wydatki na opiekę lekarską i środki lecznicze z wynagrodzenia pieniężnego należącego się pracownikowi. Potrącenia dokonywano z najbliższej wypłaty wynagrodzenia, jaką pracownik miał otrzymać, a gdyby jedna wypłata nie wystarczała, można było dokonać potrącenia z następnej. Natomiast na podstawie $\S 4$ art. 462 k.z. pracodawca nie miał tych obowiązków, jeżeli stosunek pracy zawiązany był jedynie na czas przemijającej potrzeby, a nie trwał jeszcze miesiąca. Przemijającą potrzebą mogło być na przy-

92 L. Domański, Instytucje..., s. 396-397.

93 Na takim stanowisku stali J. Bloch, op. cit., s. 178; oraz Z. Fenichel, Prawo pracy. Komentarz..., s. 94.

94 J. Namitkiewicz, op. cit., s. 250.

95 Przepisy art. 462 stosowano wobec pracowników umysłowych i robotników, Z. Fenichel, Prawo pracy. Komentarz..., s. 96; R. Longchamps de Bérier, Polskie prawo..., s. 534. 
kład przygotowanie do egzaminu, przyjęcie praczki do wyprania bielizny, osoby do froterowania podłóg itp. Jednak gdyby prace przeciągnęły się powyżej miesiąca, wtedy pracodawca obciążony był na podstawie $\S 1$ art. 462 k.z. Zgodnie z $§ 5$ art. 462 k.z. obowiązki te odpadały również, gdy pracownik miał prawo do świadczeń z tytułu ubezpieczenia publiczno-prawnego na przypadek choroby. Świadczenia tego rodzaju regulował art. 95 ustawy o ubezpieczeniu społecznym z 28 marca 1933 roku (Dz.U. Nr 51/33, poz. 396) ${ }^{96}$.

W kolejnym art. 463 k.z. ${ }^{97}$ rozwinięte zostały postanowienia art. 462 k.z., w którym uregulowano wpływ zakończenia stosunku pracy na obowiązki pracodawcy wynikające z art. 462 k.z. Wedle $\S 1$ utrzymanie i opieka oraz środki lecznicze przez czas choroby należały się pracownikowi, chociażby stosunek pracy skończył się przed upływem okresów trwania obowiązków pracodawcy wymienionych $\mathrm{w}$ art. $462 \mathrm{k} . z$. Jednakże, zgodnie z $\S 2$, obowiązki te ustawały wcześniej wraz z zakończeniem stosunku pracy, jeżeli nastąpiło ono wskutek upływu czasu, na jaki stosunek był zawarty, albo na skutek wypowiedzenia dokonanego przed chorobą pracownika lub przedwczesnego rozwiązania umowy przez pracodawcę z ważnych powodów, wyjąwszy chorobę. Przepis art. 463 k.z. stanowił ius cogens.

Kolejny obowiązek pracodawcy związany z pracownikami przyjętymi w poczet domowników dotyczył pozostawienia odpowiedniego czasu do wypoczynku i praktyk religijnych. Obowiązek ten wynikał z art. 464 k.z. ${ }^{98}$ Przy oznaczeniu odpowiedniego czasu należało brać pod uwagę okoliczności konkretnego przypadku, w szczególności rodzaj pracy oraz wymaganie dobrej wiary i zwyczaje uczciwego obrotu. Pracodawca zobowiązany był też zapewnić pracownikowi odpowiedni czas do praktyk religijnych i to nie tylko w dni świąteczne, lecz także w powszednie, jeśli pracownik miał taką potrzebę (art. 189 k.z.). Jeżeli pracodawca uchybił wskazanym obowiązkom, mogło być to potraktowane za ważny powód do odstąpienia przez pracownika od umowy pracy i przedwczesnego rozwiązania stosunku pracy (art. 470 k.z.).

Z kolei według art. 465 k.z. jeżeli pracownikowi, dla którego stosunek pracy stanowił wyłączne lub główne źródło utrzymania, pracodawca po rocznym trwaniu stosunku zobowiązany był corocznie, w terminie przez siebie oznaczonym, udzielić urlopu tygodniowego. W trakcie urlopu pracownik miał prawo do wynagrodzenia, jakie otrzymywał przy pełnieniu pracy. Artykuł 465 k.z. ${ }^{99}$ nie miał

96 L. Domański, Instytucje..., s. 399-401; Z. Fenichel, Prawo pracy. Komentarz..., s. 96-98.

97 Art. 463 stosowano także w stosunku do pracowników umysłowych i robotników z zastrzeżeniem regulacji związanych $\mathrm{z}$ wypowiedzeniem umowy o pracę w czasie choroby, czyli art. 29 rozp. o um. o pr. prac. um. oraz art. 11 rozp. o um. o pr. rob., zob. L. Domański, Instytucje..., s. 402.

98 Art. 464 stosowano także w stosunku do pracowników umysłowych i robotników, Z. Fenichel, Prawo pracy. Komentarz..., s. 99.

99 Art. 465 k.z. obowiązywał na obszarze górnośląskiej części województwa śląskiego dopiero po wejściu w życie ustawy Sejmu Śląskiego z 26 marca 1935 roku, zob. art. 34 przepisów wprowadzających k.z. 
zastosowania do pracowników podlegającym przepisom ustawy z dnia 16 maja 1922 roku o urlopach dla pracowników zatrudnionych w przemyśle i handlu (Dz.U. Nr. 40/22, poz. 334), ze zmianami wprowadzonymi przez ustawę z dnia 22 marca 1933 roku (Dz.U. Nr. 27/33, poz. 228). Artykuł 465 k.z. dotyczył zatem nauczycieli, służby domowej, dozorców domowych, pracowników rolnych (chyba że w tym wypadku układ zbiorowy lub orzeczenia Najwyższej Komisji Rozjemczej nie przyznawały większych praw). Pracownik miał prawo do tego urlopu tylko po przepracowaniu pełnego roku. Termin urlopu wyznaczał pracodawca, jednak nie mógł tego dokonywać w celu szykany pracownika. Pracownik nie miał wpływu na termin urlopu i nie mógł bez zezwolenia pracodawcy rozpocząć urlopu. Przepis ten uznawano jako bezwzględnie obowiązujący, a niespełnienie tego obowiązku przez pracodawcę uprawniało pracownika do odstąpienia od umowy (art. 470 k.z. $)^{100}$.

Do obowiązków pracodawcy należało jeszcze umożliwienie pracownikowi znalezienia innej pracy po zakończeniu stosunku pracy. W związku z tym pracodawca zobowiązany był do wydania świadectwa pracy ${ }^{101}$ oraz zostawienia pracownikowi czasu na poszukiwanie innej pracy ${ }^{102}$. Zgodnie z $§ 1$ art. 474 k.z. ${ }^{103}$ pracodawca zobowiązany był na żądanie pracownika wydać mu piśmienne świadectwo o czasie i rodzaju pracy oraz zwrócić mu świadectwa i inne dokumenty, jakie ma na przechowaniu. Gdyby pracodawca odmówił pracownikowi wydania świadectwa, pracownik mógł domagać się sądowego ustalenia tych okoliczności i wynagrodzenia za szkodę. Jednak pracownik nie mógł wymagać, aby w świadectwie była oznaczona wysokość otrzymywanego wynagrodzenia za pracę i ocena jego pracy. Wedle $\S 2$ art. 474 k.z. w świadectwie nie wolno było zamieszczać uwag, które mogły utrudnić pracownikowi otrzymanie innego zatrudnienia. Mowa o uwagach ujemnych o kwalifikacjach i zachowaniu się pracownika. Zakaz nie dotyczył jednak udzielania przez pracodawcę zgodnych z rzeczywistością informacji o kwalifikacjach i zachowaniu się pracownika osobom, które się po nie zgłaszały ${ }^{104}$. W razie naruszenia przepisów art. 474 k.z., czyli niewydania świadectwa na piśmie, zwłoki w wydaniu świadectwa, podaniu w świadectwie danych nieprawdziwych lub umieszczenia uwag ujemnych, pracodawca miał obowiązek wynagrodzenia przez to spowodowanej szkody (art. 239 k.z.) ${ }^{105}$.

100 Z. Fenichel, Prawo pracy. Komentarz..., s. 98-102.

101 Szerzej o świadectwie pracy, zob. Z. Fenichel, Świadectwo pracy, [w:] Polskie prawo prywatne i procesowe..., s. 335-342.

102 R. Longchamps de Bérier, Polskie prawo..., s. 534-535.

103 Pracownicy umysłowi i robotnicy nie podlegali tym przepisom ze względu na unormowanie tej kwestii w rozp. o um. o pr. prac. um. (art. 24) i rozp. o um. o pr. rob. (art. 21), L. Domański, Instytucje..., s. 430.

104 Odmiennego zdania był J. Namitkiewicz, który uważał, że zakaz szkodliwych uwag miał również w takim przypadku zastosowanie, zob. idem, op. cit., s. 277.

105 J. Korzonek, I. Rosenblüth, op. cit., s. 1130. 
Zgodnie z $§ 1$ art. 475 k.z. ${ }^{106}$ pracownik po wypowiedzeniu umowy zawartej na czas nieokreślony, przez pracodawcę lub przez samego pracownika, mógł żądać od pracodawcy wyznaczenia odpowiedniego czasu na poszukiwanie innej pracy, jeżeli rodzaj zajęcia przeszkadzał w tym pracownikowi, nie uszczuplając wynagrodzenia. Jeżeli pracodawca odmówił pracownikowi pozostawienia czasu na poszukiwanie innej pracy, a czasu tego nie określała ani umowa stron, ani ustawa, wtedy zgodnie z $\S 2$ art. 475 k.z. czas ten wyznaczał inspektor pracy, a w razie jego braku w danej miejscowości — sąd pracy lub sąd grodzki według miejsca wykonywania pracy lub położenia zakładu pracy ${ }^{107}$.

\section{Zakończenie}

Przepisy normujące obowiązki stron w umowie o pracę w k.z., podobnie jak pozostałe przepisy o umowie o pracę w k.z., miały poważne znaczenie socjalne i gospodarcze dla znacznej części ludności. Szczególnie istotne było to dla tych kategorii pracowników, dla których do momentu wejścia w życie k.z. nie wydano ustawy szczególnej, czyli dla nauczycieli domowych, służby domowej, a częściowo również dozorców domowych i robotników rolnych, których stosunek pracy normowały układy zbiorowe pracy lub orzeczenia komisji rozjemczych. W stosunku do pozostałych kategorii pracowników przepisy o umowie o pracę w k.z. odgrywały rolę norm prawnych uzupełniających lub wspomagających, a nie norm poprawiających lub zmieniających. W związku z tym przepisy k.z. w zakresie umowy o pracę odnośnie do dwóch podstawowych kategorii pracowników, czyli pracowników umysłowych oraz robotników, miały charakter posiłkowy ${ }^{108}$. Porównując przepisy dotyczące obowiązków stron znajdujących się w k.z. i w rozp. o um. o pr. prac. um. i rozp. o um. o pr. rob. oraz regulacje dotyczące umowy o pracę w kodeksach pozaborowych, można zauważyć, że przepisy kodeksowe stały na wyższym poziomie legislacyjnym, były lepiej opracowane, usystematyzowane i uwzględniały nadrzędność interesu pracowniczego ${ }^{109}$. Odpowiadały one ówczesnym tendencjom rozwojowym i uwzględniały interes pracownika, realizując w ten sposób tak zwaną socjalizację prawa prywatnego. Przeanalizowane obowiązki pracodawcy i wynikające $\mathrm{z}$ tego prawa pracownika

106 Postanowienia art. 475 k.z. miały zastosowanie do robotników, lecz nie obejmowały pracowników umysłowych ze względu na art. 30 rozp. o um. o pr. prac. um.

107 L. Domański, Instytucje..., s. 431.

108 L. Górnicki, op. cit., s. 161-165.

109 S. Płaza, Historia praw w Polsce na tle porównawczym, cz. 3. Okres międzywojenny, Kraków 2001, s. 279-280; A. Dral, Rys historyczny prawa pracy w okresie międzywojennym, [w:] Ochrona pracy w okresie międzywojennym w Polsce, red. K. Dąbrowski, S. Kwiecień, Lublin 2015, s. 34-35. 
wyraźnie podkreślają realizację zasady uspołecznienia w k.z. Przepisy dotyczące obowiązków stron w k.z. często były przepisami bezwzględnie obowiązującymi, o charakterze publicznoprawnym. Należy tu wymienić obowiązek przyzwoitego obchodzenia się z pracownikiem i szanowanie jego godności osobistej (art. 449 k.z.), zachowanie prawa do wynagrodzenia mimo przeszkód w pełnieniu pracy, dotyczących osoby pracownika (art. 457, 458 i 459 k.z.), obowiązki pieczy ze względu na lokal pracy, narzędzia, mieszkanie i żywność (art. 461 k.z.) oraz, w razie choroby pracowników przyjętych w poczet domowników (art. 462 k.z.), zakaz umieszczania $\mathrm{w}$ świadectwach pracy uwag, które mogłyby utrudnić pracownikowi otrzymanie innego zatrudnienia (art. $474 \S 2$ k.z.). Poza tym w k.z. znalazły się przepisy, które formalnie nie miały charakteru ius cogentis, jednak prawie zawsze znajdowały zastosowanie, ponieważ umowa przeciwna była mało prawdopodobna, a mogła zostać uznana za sprzeczną z dobrymi obyczajami. Zaliczyć tu można przepis o obowiązku dostarczenia pracownikowi akordowemu odpowiedniej pracy lub stosownego wynagrodzenia za czas stracony (art. 456 k.z.), o obowiązku zapłacenia pracownikowi znajdującemu się w potrzebie wynagrodzenia przed terminem płatności za pracę już wypełnioną, jeżeli mógł to uczynić bez szkody dla siebie (art. 457 k.z.), o obowiązku pozostawienia pracownikom przyjętym w poczet domowników odpowiedniego czasu do wypoczynku i praktyk religijnych (art. 464 k.z.), o obowiązku udzielenia tygodniowego urlopu (art. 465 k.z.) czy o obowiązku pozostawienia pracownikowi po wypowiedzeniu odpowiedniego czasu na poszukanie pracy (art. 475 k.z.) ${ }^{110}$. O wysokim poziomie przepisów o umowie o pracę, w tym przede wszystkim przepisów o obowiązkach stron, może świadczyć w miarę jednolita ocena poszczególnych przepisów przez przedstawicieli doktryny. Tezę tę potwierdza również niewielka liczba orzeczeń Sądu Najwyższego w zakresie przepisów dotyczących obowiązków stron.

\section{Bibliografia}

\section{Źródła prawa}

Ustawa z dnia z 24 maja 1860 roku o sądach wiejskich w Królestwie Polskim (Dz.Pr. t. 57, Nr 172). Ustawa z dnia 18 grudnia 1919 roku o czasie pracy w przemyśle i handlu (Dz.U. z 1920 r. Nr 2, poz. 7).

Ustawa z dnia 23 stycznia 1920 roku o rozszerzeniu działania przepisów ustawy o załatwianiu zatargów zbiorowych pomiędzy pracodawcami a pracownikami rolnymi na zatargi zbiorowe miedzy właścicielami nieruchomości miejskich a dozorcami domowymi (Dz.U. z 1920 r. Nr 8, poz. 53).

Ustawa z dnia 16 maja 1922 roku w przedmiocie powołania Nadzwyczajnej Komisji Rozjemczej do załatwiania zatargów zbiorowych pomiędzy właścicielami nieruchomości miejskich a dozorcami domowymi (Dz.U. z 1922 r. Nr 39, poz. 324).

110 L. Górnicki, op. cit., s. 161-166. 
Ustawa z dnia 16 maja 1922 roku o urlopach dla pracowników zatrudnionych w przemyśle i handlu (Dz.U. z 1922 r. Nr 40, poz. 334).

Ustawa z dnia 2 sierpnia 1924 roku w przedmiocie pracy młodocianych i kobiet (Dz.U. z 1924 r. $\mathrm{Nr} 65$, poz. 636).

Ustawa z dnia 28 marca 1933 roku o ubezpieczeniu społecznym (Dz.U. R.P. Nr. 51, poz. 396).

Ustawa z dnia 5 marca 1934 roku o załatwianiu zatargów zbiorowych pomiędzy właścicielami nieruchomości miejskich a dozorcami domowymi w woj. poznańskim (Dz.U. z 1934 r. Nr 26, poz. 198).

Rozporządzenie Prezydenta Rzeczypospolitej z dnia 4 czerwca 1927 roku o ochronie rynku pracy (Dz.U. z 1927 r. Nr 54, poz. 472).

Rozporządzenie Prezydenta Rzeczypospolitej z dnia 7 czerwca 1927 roku o prawie przemysłowym (Dz.U. z 1927 r. Nr 53, poz. 468).

Rozporządzenie Prezydenta Rzeczypospolitej z dnia 14 lipca 1927 roku o inspekcji pracy (Dz.U. z 1927 r. Nr 67, poz. 590).

Rozporządzenie Prezydenta Rzeczypospolitej z dnia 16 marca 1928 roku o umowie pracę pracowników umysłowych (Dz.U. z 1928 r. Nr 35, poz. 323).

Rozporządzenie Prezydenta Rzeczypospolitej z dnia 16 marca 1928 roku o umowie o pracę robotników (Dz.U. z 1928 r. Nr 35, poz. 324).

Rozporządzenie Prezydenta Rzeczypospolitej z dnia 16 marca 1928 roku o bezpieczeństwie i higienie pracy (Dz.U. z 1928 r. Nr 35, poz. 325).

Rozporządzenie Prezydenta Rzeczypospolitej z dnia 27 października 1933 roku — Kodeks zobowiązań (Dz.U. z 1933 r. Nr 82, poz. 598).

Rozporządzenie Prezydenta Rzeczypospolitej z dnia 24 października 1934 roku Prawo o sądach pracy (Dz.U. z 1934 r. Nr 95, poz. 854).

Rozporządzenie Prezydenta Rzeczypospolitej z dnia 27 października 1933 roku - Przepisy wprowadzające Kodeks zobowiązań (Dz.U. z 1933 r. Nr 82, poz. 599).

Rozporządzenia Prezydenta Rzeczypospolitej z dnia 27 października 1933 roku (Dz.U. z 1933 r. $\mathrm{Nr} 85$, poz. 646).

Rozporządzenie Ministra Opieki Społecznej z dnia 29 marca 1934 roku w sprawie książeczek obrachunkowych dla robotników portowych (Dz.U. z 1934 r. Nr 32, poz. 289).

Rozporządzenie Ministra Opieki Społecznej z dnia 27 marca 1935 roku o Biurze Pośrednictwa pracy dla robotników portowych w Gdyni (Dz.U. z 1935 r. Nr 23, poz. 153).

\section{Orzecznictwo}

Orzeczenie SN (S.N. Zb. Urz. 146/34).

Orzeczenie SN z dnia 4 listopada 1936 roku (S.N. Zb. 433/37, C I 1749/36).

Orzeczenie SN z dnia 1 marca 1938 roku (C II. 2157/37, P.P.P. z r. 1939, Nr I, s. 30).

Orzeczenie SN z dnia 21 czerwca 1938 roku (C. II. 3307/37, N. K. Z. z 1939 r., Nr 6, s. 19).

Orzeczenie SN z dnia 19 sierpnia 1938 roku (C. I. 606/38, N. K. Z. z 1938 r., Nr 51-52, s. 179).

\section{Literatura}

Ajnenkiel A., Położenie prawne robotników rolnych w Polsce (1918-1939), Warszawa 1962.

Basseches J., Korkis I., Kodeks zobowiazań. Przepisy wprowadzające kodeks zobowiazań, Lwów 1934.

Baszak Ł., Regulacje prawne umowy o pracę pracowników umystowych w latach 1928-1939, „Folia Iuridica Universitatis Wratislaviensis" 2016, nr 5. 
Baszak Ł., Regulacje prawne umowy o prace robotników w latach 1928-1939, „,Folia Iuridica Universitatis Wratislaviensis" 2017, $\mathrm{nr} 2$.

Bloch J., Kodeks pracy, Warszawa 1936.

Domański L., Instytucje kodeksu zobowiązań. Część szczególna, Warszawa 1938.

Domański L., Zbieg przepisów kodeksu zobowiązań o umowie o pracę z przepisami ustaw szczególnych, „Nowy Kodeks Zobowiązań” 1935, nr 45-48.

Dorożała T., Prawa pracowników w świetle kodeksu zobowiazań, „Notarjat-Hipoteka” 4, 1934, nr 25.

Dral A., Rys historyczny prawa pracy w okresie międzywojennym, [w:] Ochrona pracy w okresie międzywojennym w Polsce, red. K. Dąbrowski, S. Kwiecień, Lublin 2015.

Fenichel Z., Charakterystyka przepisów o umowie o pracę w kodeksie zobowiąań, [w:] idem, Polskie prawo prywatne i procesowe. Studia, Kraków 1936.

Fenichel Z., Prawo pracy. Komentarz, Kraków-Warszawa 1939.

Fenichel Z., Prawo pracy pracowników rolnych w Polsce, [w:] idem, Polskie prawo prywatne i procesowe. Studia, Kraków 1936.

Fenichel Z., Świadectwo pracy, [w:] idem, Polskie prawo prywatne i procesowe. Studia, Kraków 1936.

Fisch H., Problem socjalny w polskim kodeksie zobowiązań, „Nowy Kodeks Zobowiązań” 1935, nr 11.

Grzybowski S.M., Prawo pracy, „Współczesne Polskie Prawo Prywatne” 1948, z. 8.

Grzybowski S.M., Wstęp do nauki prawa pracy, Kraków 1947.

Górnicki L., Zasada uspołecznienia pewnych stosunków umownych w kodeksie zobowiąań z 1933 roku, [w:] Zasady prawne $w$ dziejach praw publicznego i prywatnego, red. M. Podkowski, Wrocław 2015.

Górski J., Umowa o pracę a zlecenia w świetle nauki i judykatury, „Głos Prawników Śląskich” 1, 3, 1939.

Jończyk J., Ochrona pracy kobiet i młodocianych w polskim przemyśle w latach 1918-1939, Warszawa 1961.

Korzonek J., Rosenblüth I., Kodeks zobowiazań. Komentarz, Kraków 1936.

Longchamps de Bérier R., Kodeks zobowiązań a dotychczasowe prawo pracy, „Nowy Kodeks Zobowiązań" 1934, nr 9.

Longchamps de Bérier R., Polskie prawo cywilne, t. 2. Zobowiązania, Lwów 1938.

Namitkiewicz J., Kodeks zobowiązań. Komentarz, t. 2, Łódź 1949.

Peiper L., Kodeks zobowiazań z dnia 27 października 1933, Dz.U. 82, poz. 598, tudzież przepisy wprowadzajace tenże kodeks z dnia 27 października 1933, Dz.U. 82, poz. 599: wraz z motywami referentów komisji kodyfikacyjnej oraz orzecznictwem polskiem, austrjackiem, francuskiem, niemieckiem i rosyjskiem, Kraków 1934.

Płaza S., Historia praw w Polsce na tle porównawczym, cz. 3. Okres międzywojenny, Kraków 2001. Rosenblüth I., Polskie prawo pracy, Kraków 1935.

Rosenblüth I., Pracy prawo, [w:] Encyklopedia podręczna prawa prywatnego, t. 3, Warszawa 1937.

Rosenblüth I., Uktady zbiorowe pracy: komentarz. Ustawa o uktadach zbiorowych pracy. Rozporządzenia wykonawcze. Wyciagi z motywów ustawodawczych. Przepisy zwiazkowe. Zatargi zbiorowe. Wzory uktadów zbiorowych pracy i innych aktów prawnych, Kraków 1937.

Święcicki M., Instytucje polskiego prawa pracy w latach 1918-1939, Warszawa 1960.

Till E., Longchamps de Bérier R., Polskie prawo zobowiazań (część szczegółowa). Projekt wstępny z motywami, Lwów 1928.

Zoll F., Zobowiązania w zarysie wedtug polskiego kodeksu zobowiązań, Warszawa 1948.

Prawo 325, 2018

(C) for this edition by CNS 


\title{
Obligations of the parties in employment contracts in the 1933 Code of Obligations
}

\author{
Summary
}

Alongside white-collar workers, labourers were the most significant group of workers in the Second Polish Republic. In 1928 the legislator decided to issue a special regulation concerning employment contracts for labourers. The provisions of the regulation were not rescinded even by the entry into force of the Code of Obligations of 1934, Articles 441-477 of which regulated employment contracts. The provisions of the Code of Obligations were only subsidiary to the provisions of the regulation.

In the article the author discusses the legal provisions concerning employment contracts in 1928-1939, i.e. when the Labourer Employment Contract Regulation and Code of Obligations were in force. He examines the provisions of the Labourer Employment Contract Regulation in connection with the White-Collar Employment Contract Regulation and the provisions of the Code of Obligations concerning employment contracts.

Keywords: employment contract, labourers, Labourer Employment Contract Regulation, White-Collar Employment Contract Regulation, Code of Obligations

\section{Die Pflichten der Parteien eines Arbeitsvertrages nach dem polnischen Schuldrechtsbuch aus dem Jahre 1933}

\section{Zusammenfassung}

In dem Aufsatz wurden die Vorschriften über den Arbeitsvertrag im polnischen Schuldrechtsbuch aus dem Jahre 1933 betreffend die Pflichten der Parteien vorgestellt. Einer eingehenden Analyse wurden vor allem die Vorschriften der Artikel 447-465 und 474-475 des Schuldrechtsbuches unterzogen. Diese wurden hinsichtlich ihrer Vollständigkeit, des Niveaus der rechtlichen Ausarbeitung, der Motive der Autoren des Schuldrechtsbuches, wie auch der Relation zwischen diesen Artikeln und den Vorschriften der Verordnung über den Arbeitsvertrag der Angestellten und der Verordnung über den Arbeitsvertrag der Arbeiter aus dem Jahre 1928 analysiert. Die Untersuchung der betroffenen Vorschriften basiert vor allen auf den Meinungen der Lehre der Zwischenkriegszeit. Um die praktische Anwendung der Vorschriften übééer die Pflichten der Parteien eines Arbeitsvertrages nach dem Schuldrechtsbuch zu überprüfen, wurden auch ausgewählte Entscheidungen des Obersten Gerichtes angeführt.

Schlüsselworte: Arbeitsrecht in der Zweiten Polnischen Republik, Arbeitsvertrag, Schuldrechtsbuch, Arbeiter, Angestellte, Verordnung über den Arbeitsvertrag der Arbeiter, Verordnung über den Arbeitsvertrag der Angestellten 